\title{
Limiting the Younger Doctrine: A Critique and Proposal
}

In Younger v. Harris ${ }^{1}$ and subsequent cases, the United States Suprenie Court has fashioned a rule of "equitable restraint" limits federal court interference with state judicial proceedings. ${ }^{3}$ A federal court, except in extraordinary circunistances, is barred from granting injunctive or declaratory rehef from an alleged deprivation of constitutional rights under "color of State law," if the constitutional

1. 401 U.S. 37 (1971).

2. No consensus has developed on a label for the doctrine emanating from Younger v. Harris. Recent Supreme Court opinions have merely referred generally to the "primciples of Younger." See Trainor v. Hernandez, 431 U.S. 434, 444 (1977); Juidice v. Vail, 430 U.S. 327, 334 (1977). This Comment adopts the term "equitable restraint." See Kugler v. Helfant, 421 U.S. 117, 124 (1975); O'Shea v. Littleton, 414 U.S. 488, 502 (1974). Although even this term is a misnomer to the extent that it iniphes that equitable, rather than federahist, values are the prinary bases for restraint, it is preferable to characterization as "abstention," see Colorado River Water Conserv. Dist. v. United States, 424 U.S. 800, 816 (1976), since to use the latter term would create a risk of confusion with the doctrine of Pullman abstention. See Railroad Comm'n v. Pullman Co., 312 U.S. 496 (1941). This doctrine is applied when state action is challenged in federal court under both state and federal law. If the federal court finds that the state law is unclear and subject to a construction which would dispose of the case entirely, it retains jurisdiction, directs the plaintiff to initiate suit in state court, and postpones its decision to avoid preinature adjudication of a constitutional issue. Id. at 501. See also England v. Louisiana State Bd. of Med. Exaininers, 375 U.S. 411, 421-22 (1964). Pullman abstention is invoked only when state law is anbiguous. Equitable restraint, by contrast, is invoked when the federal plaintiff is already a party to certain types of state proceedings, regardless of the anbiguity of state law. The federal court dismisses rather than postpones the case, and the federal claims are left to decision by the state court. See, e.g., Trainor, 431 U.S. at 441.

3. The doctrime has received much commentary. Particularly helpful guides to the history and policy of equitable restraint are Fiss, Doinbrowski, 86 YALE L.J. 1103 (1977); Whitten, Federal Declaratory and Injunctive Interference with State Court Proceedings: The Supreme Court and the Limits of Judicial Discretion, 53 N.C.L. REv. 591 (1975); Developments in the Law-Section 1983 and Federalism, 90 HARv. L. Rev. 1133, 1274-1330 (1977) [hereinafter citcd as Developments]; Comment, Post-Younger Excesses in the Doctrine of Equitable Restraint: A Critical Analysis, 1976 Duke L.J. 523 [hereinafter cited as Post-Younger Excesses].

4. To date, every case applying the Younger doctrine has been brought under 42 U.S.C. $\S 1983$ (1976), the recodification of a portion of the Civil Rights Act of 1871 (Act of Apr. 20, 1871, ch. $22, \S 1,17$ Stat. 13). It provides:

Every person who, under color of any statute, ordinance, regulation, custoin, or usage, of any State or Territory, subjects, or causes to be subjected, any citizen of the United States or other person within the jurisdiction thereof to the deprivation of any rights, privileges, or immunities secured by the Constitution and laws, shall be liable to the party injured in an action at law, suit im equity, or other proper proceeding for redress.

The jurisdictional counterpart of $\S 1983$, also originally part of $\S 1$ of the Civil Rights Act of 1871 , is now codified at 28 U.S.C $\$ 1343(3)$ (1976). \& 1343 provides:

The district courts shall have original jurisdiction of any civil action authorized by law to be commenced by any person: . . .3) to redress the deprivation, under color of any State law, statute, ordinance, regulation, custom or usage, of any right, privilege or ininunity 
claim can be presented in the pending state proceeding. 5

Critics have charged that such deference to the state courts undermines the duty of the federal courts to act as the "primary and powerful reliances"6 for the protection of constitutional rights. ${ }^{7}$ Fearing that the state courts inay often fail to vindicate these rights, these critics have sought to limit the Younger doctrine. Since the Supreine Court has not yet extended the doctrine to all state court proceedings, ${ }^{8}$ limitations based on the type of state proceeding have been suggested. ${ }^{9}$ The most popular current idea is that equitable restraint should not be required unless the state initiated the state proceeding. ${ }^{10}$

secured by the Constitution of the United States or by any Act of Congress providing for equal rights of citizens or of all persons within the jurisdiction of the United States. . . .

Despite the slightly different wording of the two sections, § 1343(3) provides federal jurisdiction for any claim brought under $\S 1983$ alleging constitutional violations. See Lyncl v. Houseliold Fin. Corp., 405 U.S. 538, 543 n.7 (1972).

5. The Younger doctrine has also been suggested as an alternate holding even where no state proceeding was pending against the federal plaintiff. Rizzo v. Goode, 423 U.S. 362, 380 (1976); O'Shea v. Littleton, 414 U.S. 488, $499-504$ (1974). These cases represent a significant departure froin the usual Younger analysis. See, e.g., Wooley v. Maynard, 430 U.S. 705,711 (1977); Doran v. Salein Inn, Inc., 422 U.S. 922, 930-31 (1975); Steffel v. Thompson, 415 U.S. 452, 462 (1974).

6. The oft-quoted term was used to describe the effect of the Judiciary Act of 1875 , conferring general federal question jurisdiction on the federal courts: "[they thereby] ceased to be restricted tribunals of fair dealing between citizens of different states and becaine the primary and powerful reliances for vindicating every right given by the Constitution, the laws, and treaties of the United States." F. FrankfurTer \& J. LANDIs, The Business of the Supreme Court 65 (1928). See Steffel v. Thompson, 415 U.S. 452,464 (1974); Zwickler v. Koota, 389 U.S. 241, 247 (1967).

7. See, eg., Trainor v. Hernandez, 431 U.S. 434, 456 (1977) (Brennan, J., dissenting); Fiss, supra note 3; McCormack, Federalism and Section 1983: Limitations on Judicial Enforcement of Constitutional Claims, 60 VA. L. REv. 250 (1974); McMillan, Abstention-The Judiciary's SelfInficted Wound, 56 N.C.L. REv. 527 (1978); Redisl, The Doctrine of Younger v. Harris: Deference in Search of a Rationale, 63 CoRNELL L. Rev. 463 (1978); Shaman \& Turkington, Huffinan v. Pursue, Ltd.: The Federal Courthouse Door Closes Further, 56 B.U.L. REv. 907 (1976); Soifer \& Macgill, The Younger Doctrine: Reconstructing Reconstruction, SS TEXAs L. REv. 1141 (1977); Developments, supra note 3, at 1274-1330; Post-Younger Excesses, supra note 3; Note, The New Federal Comity; Pursuit of Younger in a Civil Context, 61 IowA L. Rev. 784 (1976) [hereinafter cited as Federal Comity]; Note, Younger Grows Older: Equitable Abstention in Civil Proceedings, 50 N.Y.U.L. REv. 870 (1975) [hereinafter cited as Younger Grows Older].

8. See note 47 and accompanying text infra.

9. The earliest suggestion - that equitable restraint was required toward criminal but not civil proceedings, see Younger, 401 U.S. at 55-56 (Stewart, J., concurring)-was soon rejected by the Court in Huffman v. Pursue, Ltd., 420 U.S. 592, 604 (1975) (requiring restraint toward civil "public nuisance" action by state against adult movie theater).

10. This proposal was inost recently articulated in Jolinson v. Kelly, 583 F.2d 1242 (3d Cir. 1978) (Seitz, C.J.). Pennsylvania homeowners petitioned the United States District Court for declaratory and injunctive relief froin pending state quiet title actions brought by private parties who had bought their hoines at county tax sales. Id. at $1244-45$. They claimed that the tax sales were unconstitutional as repugnant to the due process clanse of the fourteenth amendinent. Id. at 1245. The district court disnnissed the complaint on Younger grounds. Id. The Third Circuit reversed, finding that the district court's action was "fundamentally inconsistent with Congress' decision to create in 42 U.S.C. $\$ 1983$ a federal forun for the adjudication of constitutional claims such as 
This Comment will argue that the analyses of both the Court and its critics are misguided and inconsistent. Although the excesses of equitable restraint must be curbed, the proposed limitation based on state initiation, even if not foreclosed by Court decisions, ${ }^{11}$ should be rejected. The proposal fails to afford adequate protection to either the state or federal interests implicated by federal imterference with pendmg state proceedings to protect constitutional rights. Neither the state interest in the regular operation of its courts nor the federal interest in the full and fair adjudication of constitutional claims depends on whether the state mitiated the pending state proceeding.

This Comment suggests a new approacl for balancing these competing interests, one that focuses on the adequacy of the state proceeding. The Younger doctrine now requires such an inquiry, but it has been so deferentially conducted that the constitutional claimant is often relegated to dubious state remedies. ${ }^{12}$ A new node of inquiry for eval-

this one." Id. at 1252. The circuit court then held that "outside the special context of a challenge to civil contempt proceedings, the Younger doctrine should not be extended to cases in which the state proceedings have not been initiated by the state itself." Id. at 1249. See also Puerto Rico Int'l Airlines v. Recio, 520 F.2d 1342, 1345 (1st Cir. 1975); Shanan \& Turkington, supra note 7; Post-Younger Excesses, supra note 3, at 557-58; Federal Comity, supra note 7, at 812; Younger Grows Older, supra note 7, at 883 n.62.

11. See Juidice v. Vail, 430 U.S. 327 (1977), which applied Younger to interference with a state court contempt proceeding arising from a suit in which the state was not a party. The lower federal courts have repeatedly held that equitable restraimt precludes federal court interference with state proceedings between purely private litigants. Lamb Enterprises, lnc. v. Kiroff, 549 F.2d 1052, 1056 (6th Cir.) (private suit for attorney's fees), cert. denied, 431 U.S. 968 (1977); Louisville Area Inter-Faith Comm. v. Nottingham Liquors, 542 F.2d 652, 654 (6th Cir. 1976) (suit by storeowner to enjoin farmworker picketing); Williams v. Williams, 532 F.2d 120, 122 (8th Cir. 1976) (adoption proceedimgs); Littleton v. Fisher, 530 F.2d 691, 693 (6th Cir. 1976) (child custody hearings in state divorce court); American Radio Ass'n v. Mobile S.S. Ass'n, 483 F.2d 1, 6 (5th Cir. 1973) (suit by marine unions to overturn state injunction agamst picketing); Cousins v. Wigoda, 463 F.2d 603, 606 (7th Cir.) (state suit by Deinocratic Party officials to enjoin delegate challenge by insurgent group at the 1972 Convention), stay denied, 409 U.S. 1201 (1972) (Rehnquist, Circuit Justice); Gras v. Stevens, 415 F. Supp. 1148, 1154 (S.D.N.Y. 1976) (divorce proceedimgs); Fisher v. Federal Nat'l Mortgage Ass'n, 360 F. Supp. 207, 210 (D. Md. 1973) (state proceedings to foreclose deed of trust securing promissory notes).

Only two lower federal courts have refused to apply equitable restraint to state civil proceedings between private hitigants: Johnson v. Kelly, 583 F.2d 1242, 1249 (3d Cir. 1978); Puerto Rico Int'l Airlines v. Recio, 520 F.2d at 1345. Chief Judge Seitz in Johnson cited other decisions as supporting the proposed linitation, but these are of doubtful value. Two cases involved requests for federal injunctive rehef from future, not pending, prosecutions: Ealy v. Littlejohn, 569 F.2d 219, 224 (5th Cir. 1978); Morial v. Judiciary Comin., 565 F.2d 295, 297 (5th Cir. 1977), cert. denied, 435 U.S. 1013 (1978). Two other cases cited by Chief Judge Seitz also did not involve pending state proceedings: D'lorio v. County of Delaware, 447 F. Supp. 229, 233 (E.D. Pa. 1978); Santiago v. City of Philadelphia, 435 F. Supp. 136, 145 (E.D. Pa. 1977). Finally, the injunction of state proceedings in the fifth case cited, Marshall v. Chase Manhattan Bank, 558 F.2d 680 (2d Cir. 1977), was based on a federal statute which, unlike $\S 1983$, conferred exclusive jurisdiction on the federal courts. Id. at 684 .

12. See, e.g., Kugler v. Helfant, 421 U.S. 117, 124 (1975); Gibson v. Berryhill, 411 U.S. 564, 577 (1973). 
uating the "adequacy" of the state proceedings is necessary to ensure the vindication of federal rights. This Comment therefore proposes that equitable restraint should be required only towards state court proceedings that provide a "plain, speedy and efficient remedy" for the federal wrong. ${ }^{13}$

The Supreme Court now seems unreceptive to limitations on Younger. Yet, the principles articulated in its own decisions require the fundamental reformulation of equitable restraint doctrine proposed here. The argument for a reformulation is also directed at Congress, which may reassert that federal courts have primary responsibility for vindicatimg constitutional rights. New legislation should be drafted to bar equitable restraint when the pending state proceeding fails to afford a "plain, speedy and efficient remedy" for the federal wrong.

\section{THE YOUNGER DOCTRINe}

\section{A. Sources of the Doctrine}

Equitable restraint, as originally formulated by Justice Black in Younger, is based on "the national policy forbidding federal courts to stay or enjoin pendimg state proceedimgs except under special circumstances." 14 This policy is derived from the Anti-Injunction Act, first passed in $1793 .{ }^{15}$ Rather than relying on the statute itself, which forbids federal injunctions of state proceedings unless, inter alia, they are "expressly authorized" by another federal statute, Justice Black based his decision on the statute's "primary sources."16 First, he noted that courts of equity traditionally denied relief when the moving party had

13. The language is borrowed from 28 U.S.C. $\$ 1341$ (1976): "The district courts shall not enjoin, suspend or restram the assessment, levy or collection of any tax under State law where a plain, speedy and efficient remedy may be had in the courts of such State."

14. 401 U.S. at 41.

15. The Act, now codified at 28 U.S.C. $\$ 2283$ (1976), provides: "A court of the United States may not grant an injunction to stay proceedings in a State court except as expressly authorized by Act of Congress, or where necessary in aid of its jurisdiction, or to protect or effectuate its judgments." The present Act is the successor to $\S 5$ of the Judiciary Act of 1793, ch. 22, $\S 5$, 1 Stat. 334 (1861); see Younger, 401 U.S. at 43. The Act also bars indirect stays of state proceedimgs by injunctions directed at the parties rather than the court itself. Oklahoma Packing Co. v. Oklahoina Gas \& Elec. Co., 309 U.S. 4, 9 (1940).

16. 401 U.S. at $43-44$. Justice Black thus avoided a decision as to whether suits brought under 42 U.S.C. $\$ 1983$, see note 4 supra, were an "expressly authorized" exception to the AntiInjunction Act. This issue had been mentioned but not resolved in previous decisions. See Cameron v. Johnson, 390 U.S. 611,613 n.3 (1968); Dombrowski v. Pfister, 380 U.S. 479, 484 n.2 (1965).

The Supreme Court has found that a number of statutes permit federal court injunctions of state proceedings as "expressly authorized" exceptions to 28 U.S.C. $\$ 2283$. These include: (1) the Bankruptcy Act, 11 U.S.C. $\$ \S 1$ to 1103 (1976); (2) the Interpleader Act of 1936, 28 U.S.C. \& 2361 (1976); see Treinies v. Sunshine Mining Co., 308 U.S. 66 (1939); (3) the Federal Habeas Corpus Act, 28 U.S.C \& 2251 (1976); see Ex parte Royall, 117 U.S. 241 (1886); (4) the Removal Act, 28 
an adequate remedy at law and would not suffer irreparable injury. ${ }^{17}$ The "more vital consideration," however, was the notion of "coinity" or "Our Federahisin,"18 a commitment to

a system in which there is sensitivity to the legitimate imterests of both State and National Governments, and in which the National Governinent, anxious though it may be to vindicate and protect federal rights and federal interests, always endeavors to do so in ways that will not unduly interfere with the legitimate activities of the States. ${ }^{19}$

Under this system, federal rehef from a pending state criminal prosecution should be demed, absent a showing of irreparable injury which is "both great and immediate."20 Irreparable injury can be shown only if the federal right cannot be protected by a "defense against a single criminal prosecution." 21 The state prosecution itself, which will presumably vindicate federal rights, eliminates any justification for federal rehef in all but "extraordimary circumstances." 22

The policy of equitable restraint has been apphed only to cases brought under 42 U.S.C. section $1983 .{ }^{23}$ This limitation, which the Court has not exphicitly acknowledged, seeins anoinalous since Mitchum v. Foster, ${ }^{24}$ decided one year after Younger, established that section

U.S.C. $\$ 1446(c)$ (1976); see French v. Hay, 89 U.S. (22 Wall.) 250 (1875). See also Porter v. Dicken, 328 U.S. 252 (1946).

17. 401 U.S. at 43.

18. Id. at $43-44$.

Justice Black apparently regarded "comity" and "Our Federahsm" as synonymous. Id. at 44. Other commentators have chosen to distinguish "comity" as the respect and deference due other courts, even in a unitary systen. See Bartels, Avoiding a Comity of Errors: A Model for Adjudicating Federal Civil Rights Suits That "Interfere" with State Civil Procecdings, 29 Stan. L. Rev. 27, 43 (1976); Post-Younger Excesses, supra note 3, at 530. This Comment uses a similar distinction, with different terms, to describe the harm to state interests posed by federal interference with pending state proceedimgs. "Procedural federalism" refers to the state's interest in the integrity and continuity of its judicial processes. "Substantive federalisin" refers to the state's interest in the substantive state policies underlying the laws enforced in such state proceedings. See Younger Grows Older, supra note 7, at 878.

19. 401 U.S. at 44.

20. Id at 46. This standard had been established by a long line of cases involving federal rehef from pending state criminal prosecutions. Douglas v. City of Jeanette, 319 U.S. 157, 163-64 (1943); Williams v. Miller, 317 U.S. 599, 600 (1942) (per curiam); Watson v. Buck, 313 U.S. 387, 401 (1941); Beal v. Missouri \& Pac. R.R., 312 U.S. 45, 50 (1941). But see Truax v. Raich, 239 U.S. 33, 38-39 (1915) (Holines, J.) (affirming federal court injunction of state crininal prosecution).

21. Younger, 401 U.S. at 46. Younger began as a suit filed under $\$ 1983$ in federal court for declaratory and injunctive rehef from a pending state prosecution under the California Criminal Syndicalisin Statute. Id. at 38-39. A three-judge panel of the United States District Court found the statute unconstitutionally vague and overbroad and enjoined the pending prosecution. $I d$. at 40. The Supreme Court reversed, rejecting the notion suggested by Dombrowski v. Pfister, $\mathbf{3 8 0}$ U.S. 479, 485-86 (1965), that prosecution under a state statute which is unconstitutional on its face may constitute irreparable injury justifying federal rehef. 401 U.S. at 53. For a critique of the Younger treatinent of Dombrowski, see Fiss, supra note 3, at 1112.

22. 401 U.S. at 53.

23. See note 4 supra.

24. 407 U.S. 225 (1972). 
1983 is an "expressly authorized" exception to the Anti-Injunction Act. ${ }^{25}$

While the Mitchum Court cautioned that its decision did not qualify in any way "the principles of equity, comity, and federalism that must restrain a federal court when asked to enjoin a state proceeding,"26 this facile harmonization of Younger and Mitchum camiot witlstand analysis. Under the Younger doctrime, the treatment of claims brought under section 1983 for federal rehef from pending state proceedings differs markedly froin the treatinent of similar claims brought under other "expressly authorized" exceptions to the Anti-Injunction Act. In the latter cases, the Court has not derived a judicial doctrine of restraint from the Act when the Act is by its own terns inapplicable. ${ }^{27}$ Rather, the Court has deferred to the congressional decision that the need for an injunction of state proceedings outweighs the attendant harms. Yet the Court has never explicitly considered why such deference should not also be accorded to the similar congressional mandate of section 1983. In the absence of an articulated distinction, this unique treatment of section 1983 is most easily attributed to a basic hostility to the federal courts' statutorily mandated duty to act as the primary guarantors of constitutional rights. ${ }^{28}$

The propriety of equitable restraint depends on a balance of the policy, required by section 1983, of ensuring full and fair adjudication of constitutional claims and the policy, derived froin the Anti-Injunction Act, of avoiding undue interference with state interests. Such a balance requires a further examination of the intent of Congress, the past decisions of the Supreine Court, and the practical effects of forumallocation decisions.

\section{B. The Basic Rule}

The so-called "February Sextet"-Younger and five other cases decided the same day ${ }^{29}$ - held that equitable restraint is required when

25. Id. at 243 .

26. Id.

27. See cases cited at note 16 supra.

28. See, eg., Huffman v. Pursue, Ltd., 420 U.S. 592, 606 (1975). Justice Brennan has noted:

Perhaps the process of eviscerating $\S 1983$ should not come as a surprise. This Court

... has shaped the doctrines of jurisdiction, justiciability, and reinedy so as increasingly

to bar the federal courthouse door to litigants with substantial federal clanns. ...

Under the banner of vague, undefined notions of equity, comity, and federalism, the

Court has embarked upon the dangerous course of condoning both isolated . . . and systematic . . . violations of civil liberties.

Juidice v. Vail, 430 U.S. 327, 346 (1977) (Brennan, J., dissenting).

29. In addition to Younger, four of the "sextet" involved pending or completed state criminal prosecutions: Byrne v. Karalexis, 401 U.S. 216, 220 (1971); Dyson v. Stein, 401 U.S. 200, 20102 (1971); Perez v. Ledesma, 401 U.S. 82, 84 (1971); Samuels v. Mackell, 401 U.S. 66, 67 (1971). The sixth case imvolved a suit to enjoin future criminal prosecutions only. Boyle v. Landry, 401 
a federal court is petitioned for relief from a pending state criminal prosecution. Except in extraordinary circumstances, according to the "Sextet," the federal court may not enjoim ${ }^{30}$ nor otlierwise interfere ${ }^{31}$ with the state proceeding. Nor may it entertam a suit for a declaratory judgment as to the constitutionality of a state law or procedure which can be challenged in the pending state proceeding. ${ }^{32}$ Moreover, cases following Younger require that federal relief from a state court judgment must also be denied if state appellate remedies have not been exhausted..$^{33}$

Although the doctrine of equitable rcstraint was originally applied only to cases where state proceedings were pending when the federal complaint was filed, the availability of federal relief, absent a pending state proceeding, was not immediately resolved. ${ }^{34}$ Before Younger, the federal courts had allowed a section 1983 claimant access to the federal courts without first exhausting available state remedies when no state

U.S. 77, 80 (1971). The Supreme Court reversed the district court injunction on the ground that such future prosecutions were too speculative to constitute a threat of irreparable injury. Id. at 81.

30. Younger, 401 U.S. at $45,53$.

31. An injunction which does not actually stay a state prosecution, but instead effectively stifles it - by suppressing evidence, for example-is also impermissible. Perez v. Ledesma, 401 U.S. 82, 85 (1971). See Stefanelli v. Minard, 342 U.S. 117, 123 (1951).

32. Samuels v. Mackell, 401 U.S. $66,72-73$ (1971). The Court reasoned that a declaratory judgment "will result in precisely the same interference with and disruption of state proceedings" as would an injunction. Id. at 72. This is true either because a declaratory judgment would be considered "res judicata" in the state court, or because a declaratory judgment could serve as a basis for a subsequent injunction to "protect or effectuate" it, as allowed by the Anti-Injunction Act. Id. The Court's conclusion is by no means compelled, however. The collateral estoppel effect of a federal declaratory judgment on state proceedings has not been authoritatively resolved. Compare Steffel v. Thompson, 415 U.S. 452, 470-71 (1974), with id. at 477 (White, J., concurring) and id. at 479, 482 n.3 (Rehnquist, J., concurring). Moreover, the Younger doctrine itself makes clear that a determination that an mjunction is permitted by the Anti-Injunction Act does not end the inquiry. Indeed, the pohicy of equitable restraint is invoked only when the Anti-Injunction Act is not itself applicable. See Mitchum v. Foster, 407 U.S. 225, 243 (1972). Thus the Court could have held that declaratory judgments are permitted by the Younger doctrine, but that preliminary or final injunctions to "protect or effectuate" these judgments are not. See Post-Younger Excesses, supra note 3, at 545 n.99. This approach was rejected by the Court in Samuels and subsequent cases. See Wooley v. Maynard, 430 U.S. 705, 712 (1977); Doran v. Salem Iım, Inc., 422 U.S. 922, 930-31 (1975).

33. Huffinan v. Pursue, Ltd., 420 U.S. 592, 608 (1975). For an example of the divergent views of current justices on the subject, compare Byrne v. Karalexis, 401 U.S. 216, 220 (1971), with id. at 221 (Brennan, J., dissenting). The right of access to a federal court for collateral attack on a state judginent after exhaustion of state appellate reinedies and the "estoppel" effects of the prior state court judgment have not been authoritatively resolved. Huffman, 420 U.S. at 606 n.18. See Theis, Res Judicata in Civil Rights Act Cases: An Introduction 10 the Problem, 70 Nw. U.L. REv. 858 (1976); Note, The Preclusive Effect of State Judgments on Subsequent 1983 Actions, 78 CoLUM. L. REv. 610 (1978).

34. Samuels v. Mackell, 401 U.S. 66, 73-74 (1971); Younger, 401 U.S. at 41. See also O'Shea v. Littleton, 414 U.S. 488 (1974), where the Younger doctrine was mvoked as an alternative ground for denying federal rehef although no state prosecutions were pending agaimst the federal plaintiff. Id. at $499-504$. 
action was pending. ${ }^{35}$ However, this rule, based on Monroe v. Pape, ${ }^{36}$ had not been tested against the values of "equity, comity, and federalism" asserted by Younger.

The Court eventually "reconciled" Monroe and Younger by adopting the "pending prosecution rule." When no state prosecution is pending and the federal plaintiff establishes an actual "case or controversy"37_usually by showing a credible threat of prosecution ${ }^{38}$-federal relief is not barred. The federal court inay, if the other conditions for federal rehef are estabhished, grant a declaratory judginent ${ }^{39}$ or a preliminary $^{40}$ or final injunction. ${ }^{41}$

By contrast, where state criminal proceedings are initiated against a federal plaintiff after the federal coinplaint has been filed but before any substantial proceedings on the inerits have taken place in the federal court, the Supreme Court has ruled that federal relief may not be granted. ${ }^{42}$ This decision gave state prosecutors, in effect, a "reverse removal power"43 to defeat federal jurisdiction by answering federal complaints with state imdictments. ${ }^{44}$

Federal relief from allegedly unconstitutional state criminal statutes or procedures has thus been confined to an exceedingly narrow sphere. The federal plaintiff inust establish a credible threat of state prosecution but inust avoid prosecution until "substantial proceedings

35. Zwickler v. Koota, 389 U.S. 241, 248 (1967); Monroe v. Pape, 365 U.S. 167, 183 (1961); Lane v. Wilson, 307 U.S. 268, 274 (1939). Monroe has been overruled insofar as it held local governments wholly immune from suits under $\S 1983$, an issue which is irrelevant to this analysis. Monell v. Department of Social Services, 436 U.S. 658, 663 (1978).

36. 365 U.S. 167 (1961).

37. U.S. Const. art. 111, § 2, \1.

38. Federal plaintiffs who have failed to establish a credible threat of prosecution have been consistently dismissed. See, e.g., O'Shea v. Littleton, 414 U.S. 488, $493-97$ (1974); Boyle v. Landrey, 401 U.S. 77, 81 (1971); Younger, 401 U.S. at 41-42.

39. Steffel v. Thompson, 415 U.S. 452,474 (1974). The pending prosecution rule was foreshadowed by the earlier decisions in Lake Carriers Ass'n v. MacMullan, 406 U.S. 498, 509 (1972) (dicta concerning the underlying Younger doctrine "have little force in the absence of a pending state proceeding"), and Roe v. Wade, 410 U.S. 113, 124-27, 166 (1973) (reversing federal declaratory judgment for doctor facing pending state abortion prosecution on Younger grounds, but affirming declaratory relief for Roe, who apparently faced no such prosecution, without mentioning Younger).

40. Doran v. Salem Inn, Inc., 422 U.S. 922, 930-31 (1975).

41. Wooley v. Maynard, 430 U.S. 705, 709, 711-12, 717 (1974). Both Wooley and Doran involved "personalized" injunctions which restrained only state prosecutions of the named federal plaintiffs. Wooley, id. at 709; Doran, 422 U.S. at 930. See Fiss, supra note 3, at 1147-48. This limitation of injunctive relief should not be significant in practice, since a federal plaintiff facing state prosecution should normally be satisfied with only "personalized" relief.

42. Hicks v. Miranda, 422 U.S. 332,349 (1975).

43. Fiss, supra note 3 , at 1134-36.

44. Hicks, 422 U.S. at 357 (Stewart, J., dissenting). The Hicks majority exphicitly rejected the argument that the prosecutor's actions showed "bad faith" (an exception to the rule of equitable restraint). Id. at 351. See notes 68-71 and accompanying text infra. 
on the merits" have taken place in the federal court. To meet these requirements, the plaimtiff must not only file his federal complaint before state prosecution but must also obtam preliminary federal relief against such prosecution. ${ }^{45}$ Issuance of such an injunction, even when permitted by the Younger doctrine, is limited by additional requirements, including proof of a reasonable likelihood of success on the merits. $^{46}$

\section{Extension of the Younger Doctrine}

Although the Younger sextet involved only state crimimal prosecutions, the Supreme Court has gradually extended the doctrine to other types of state court actions. The Court has specifically refrained, however, from applymg the doctrine to all pending state civil proceedings. ${ }^{47}$

The first step toward restraimt in noncriminal cases was taken in Huffman v. Pursue, Ltd. ${ }^{48}$ in which the Court held that Younger barred federal mjunctive relief from a public nuisance proceeding, initiated by the county prosecutor, to close appellee's movie theater ${ }^{49}$ Justice Rehnquist, writing for the Court, set the pattern for subsequent extensions of equitable restraimt. Younger, he reasoned, had sought to prevent certaim harins to state interests. ${ }^{50}$ The regular operation of the state judicial system is inevitably disrupted by federal relief from any type of pending state proceeding, ${ }^{51}$ but the state interest in effectuating the substantive state pohicies enforced in state proceedings is much greater in the context of criminal prosecutions. ${ }^{52}$ The Younger principles therefore should apply in full force, according to Justice Rehn-

45. Doran, 422 U.S. at 930 . See Redish, supra note 7, at 475 n.76.

46. Quite apart from the policy of equitable restramt, the federal court contemplating a preliminary injunction must consider: (1) the significance of the threat of irreparable harm to plaintiff if the injunction is not granted; (2) the state of the balance between this harm and the mjury that granting the injunction would inflict on defendant; (3) the probability that plaimtiff will succeed on the merits; and (4) the public interest. 11 C. WRIGHT \& A. Miller, Federal Practice AND Procedure $\$ 2948$, at 431-32 (1973).

47. Trainor v. Hernandez, 431 U.S. 434, 444 n. 8 (1977); Juidice v. Vail, 430 U.S. 327, 336 n.13 (1977); Huffman v. Pursue, Ltd., 420 U.S. 592, 607 (1975). Justice Brennan has derided these disclaimers as "tongue in cheek," suspecting that "merely the formal announcement is being postponed." Juidice, 430 U.S. at 345 n.* (Brennan, J., dissenting).

48. 420 U.S. 592 (1975).

49. The state court ordered the closure of appellee's inovie theatre after finding certain movies displayed $\mathrm{m}$ it to be obscene. Id. at 598. Appellee then obtamed an injunction froin the United States District Court restraining the execution of the state court order insofar as it closed the theater to the display of films not judged obscene. Id. The Supreme Court vacated the distriet court's judgnient and remanded for further consideration. Id. at 612 .

50. Id. at 604 . The four harms posited by Justice Rehnquist are listed and discussed at notes 135-56 and accompanying text infra.

51. 420 U.S. at 604 .

52. Id. 
quist, only if the state interest in the substantive policies enforced in the state civil proceeding is "every bit as great as" its interest in criminal prosecutions. ${ }^{53}$ Emphasizing that the state had initiated the public nuisance proceeding which was "both in aid of and closely related to criminal statutes which prohibit the dissemination of obscene materials," Justice Rehnquist concluded that the state's interest in the nuisance proceeding was sufficiently great to require equitable restraint. ${ }^{55}$

A second extension occurred in Juidice $v$. Vail, ${ }^{56}$ which barred federal relief from a statutory contempt proceeding arising in a suit between private litigants. ${ }^{57}$ Although such conteinpt proceedings primarily serve the "private interests of competing litigants," they also protect the "authority of the judicial system." 58 The Court thus concluded that the state interest in vindicating "the regular operation of its judicial system" was sufficient to bar federal relief. ${ }^{59}$

Finally, Trainor v. Hernandez ${ }^{60}$ barred federal relief from a pending state attachment proceeding initiated by the Illinois Department of Public Aid against welfare recipients who allegedly had fraudulently concealed their assets. ${ }^{61}$ The Court stressed that the suit was "brouglit by the State in its sovereign capacity" to protect its substantial interest in the fiscal integrity of its public assistance programs, and that welfare fraud was a crime under Illinois law. ${ }^{62}$ The state interest in the pending proceeding was thus sufficient to require equitable restraint. ${ }^{63}$

Ratler than require equitable restraimt toward all pending state civil proceedings the Court has invoked the doctrine on a case-by-case

53. Id. at 604-05.

54. Id. at 604 .

55. Id. at 607 .

56. 430 U.S. 327 (1977).

57. Appellee had suffered a default judgment in a suit brought by a private creditor. When the appellee failed to appear for a subsequent deposition to give information relevant to the satisfaction of the judgment, he was cited for contempt. Id. at 329 . Vail was arrested and jailed for one day when he failed to pay his fine. $I d$. at 330 . Appellee then filed a class action, under $\$ 1983$, in federal court claiming that New York's statutory contempt procedures violated the due process clause of the fourteenth amendment. 1 d. The district court found portions of the challenged statutes unconstitutional and permanently enjoimed their enforcenent against the appellee and members of his class. Id at 331 . The Supreme Court reversed. Id. at 339.

58. Id. at $336 \mathrm{n} .12$.

59. Id. at 335.

60. 431 U.S. 434 (1977).

61. The Illinois Department of Public Aid had sued welfare recipients in state court for fraudulently concealing assets and had simultaneously instituted a state attachment proceeding against the recipients' credit union account. Id. at 435-36. The recipients then filed a federal suit inder $\S 1983$, claiming that the state attachment act was unconstitutional. Id. at 438 . The district court granted the requested declaratory and imjunctive relief. $I d$ at 439 . The Supreme Court reversed and remanded for further consideration. Id. at 447-48.

62. Id. at $435,444$.

63. Id. at 446 . Justice Blackmun concurred separately to stress the "substantiality of the State's interest," mentioning the same factors discussed above. Id. at 448-50. 
basis whenever the state interest in the substantive policies involved is of sufficient inagnitude. This approach has led critics of the doctrine to suggest limitations based on factors which arguably indicate the magnitude of the state interest, ${ }^{64}$ such as whether tlie state initiated the proceeding. ${ }^{65}$ This Comment will demonstrate, however, that the state's substantive interest in the policy furthered by the challenged statute is simply irrelevant to the need for equitable restraint. The effect on substantive state policies will be the sanie whether the state or federal court, both bound by the sanie law, adjudicates the constitutional clain1. ${ }^{66}$

\section{Exceptions to the Younger Doctrine}

Younger indicated that "extraordinary circumstances" may justify federal relief from a pending state proceeding. ${ }^{67}$ Although these exceptions have since been defined in greater detail, they have rarely been invoked to justify federal relief.

\section{Bad Faith}

In theory, federal relief is available to a constitutional claimant who has been the victim of bad faith or harassinent, ${ }^{68}$ that is, the target of a criminal prosecution "brought without a reasonable expectation of obtaining a conviction." "69 Since Younger, however, the Court has never allowed federal interference with a pending state proceeding on these grounds. ${ }^{70}$

This exception seems inconsistent with the principles underlying the Younger doctrine-i.e., that the state courts will norinally protect federal rights, reinoving any threat of "irreparable injury" that might justify federal injunctive relief. Unless the state court caimot be relied upon for full and fair adjudication of constitutional claims (an in-

64. See note 10 supra.

65. Johnson v. Kelly, 583 F.2d 1242, 1249 (3d Cir. 1978).

66. See notes $137-42$ and accompanying text infra.

67. 401 U.S. at 53.

68. Id.

69. Kugler v. Helfant, 421 U.S. 117, 126 n.6 (1975).

70. See Hicks v. Miranda, 422 U.S. 332, 351 (1975); Kugler, 421 U.S. at 126 n.6; Anonymous v. Association of the Bar, 515 F.2d 427, 434-35 (2d Cir.), cert. denied, 423 U.S. 863 (1975). Harassment or bad faith was found in Allee v. Medrano, 416 U.S. 802, 815 (1974), and in Dombrowski v. Pfister, 380 U.S. 479, 488 (1965), but neither of these cases granted relief from pending state proceedimgs. 416 U.S. at $819 ; 380$ U.S. at 484 n.2.

Dombrowski appeared to justify federal relief by stressing primarily the chilling effect on first amendment rights of the threatened state prosecution. Id. at 486-87. Younger, however, limited Dombrawski by finding that the rehef there had been justified by the fact that the prosecutions were threatened without "any expectation of securing valid convictious." Younger, 401 U.S. at 4748. The Court expressly rejected the lower federal court's interpretation of Dombrowski as allowing federal imtervention solely to prevent a chilling effect on first amendment rights. 
dependent exception to the Younger doctrine), prosecutorial bad faith presents no threat of irreparable injury. ${ }^{71}$

\section{A Flagrantly Unconstitutional Statute}

Younger also suggested that federal relief may be justified when the challenged state statute is "flagrantly and patently violative of express constitutional prohibitions in every clause, sentence, and paragraph, and im whatever manner and against whoinever an effort nnight be inade to apply it."72 The Court has not clarified this standard, except to suggest that it is to be strictly applied. ${ }^{73}$ Like the "bad faith" exception, the "flagrantly unconstitutional statute" exception has never been successfully invoked. And, like the "bad faith" exception, this exception seems inconsistent with the principles underlying equitable restraint. If the Supreme Court's confidence in the state courts is justifled, those courts can surely be trusted with "easy" cases of flagrant unconstitutionality.

\section{Inadequate State Proceedings}

The policy of equitable restramt is premised on the assumption that "ordinarily a pending state prosecution provides the accused a fair and sufficient opportunity for vindication of federal constitutional rights. . . . Only . . . 'extraordinary circumstances' [warrant] any relaxation of the deference to be accorded to the state criminal process."74 The Court lias indicated only two such exceptional circumstances which render state courts incapable of vindicating constitutional rights: bias and inability to present the constitutional claims.

Even these exceptions are limited. The federal plaintiff must bear a heavy burden of proof to overcoine the presumed adequacy of the state courts. ${ }^{75}$ Moreover, the deference of the Court's inquiry has approached neglect. ${ }^{76}$

71. For example, the state court in Dombrowski, 380 U.S. at 487-88, quashed arrest warrants, obtaincd in bad faith by the prosecutors, as being "uot based on probable cause."

72. 401 U.S. at 53-54 (quoting Watson v. Buck, 313 U.S. 387, 402 (1941)).

73. See Trainor v. Hernandez, 431 U.S. 434 (1977), where the Court curtly reversed a district court decision that the Illinois Attachment Act was "flagrantly unconstitutional" as "not warranted in light of our cases." Id. at 446-47.

74. Kugler, 421 U.S. at 124.

75. See Kugler, 421 U.S. at 125 ("an extraordinarily pressing need for immediate federal equitable relief"); Younger, 401 U.S. at 45 (quoting Fenner v. Boykin, 271 U.S. 240, 243-44 (1926)) (inadequacy must "plainly appear").

76. See, e.g., O'Sliea v. Littleton, 414 U.S. 488 (1974), which involved a class action by black residents of Cairo, Illinois, seeking injunctive relief from the allegedly discriminatory sentencing and boud-setting practices of two county judges. Id. at 490-92. Justice White, speaking for the Court, lield that the named plaintiffs, none of whoun were facing pending criminal charges or serving allegedly illegal sentences, failed to present an "actual case or controversy," id. at 493, 496, and that fcderal rehef was also independently barred by the doctrine of equitable restraint, id. at 


\section{a. Bias}

Federal relief is not barred when the state tribunal is "incoinpetent by reason of bias to adjudicate the issues pending before it." judicial review, de novo or otherwise, of the biased tribunal is irrelevant. $^{78}$

This exception has hitherto allowed federal relief only when the state forum had a pecuniary interest in the outcoine of the proceedings. ${ }^{79}$ The Court has suggested that allegations of "bias" will not justify federal relief if there is a state procedure for the disqualification of biased judges, even though that procedure leaves disqualification to the discretion of the allegedly biased judge. ${ }^{80}$

\section{b. Inability to Present a Federal Claim}

Federal relief is not barred when the federal plaintiff can prove that presentation of his constitutional claim in the state proceeding is impossible. ${ }^{81}$ This exception, however, has never been invoked by the Supreme Court to justify federal relief from a pending state proceedimg. ${ }^{82}$

504. A number of state and federal procedures were "available" for "relief from the wrongful conduct alleged": (a) substitution of judges; (b) change of venue; (c) state disciplinary procedures; (d) appellate review; (e) federal habeas corpus; and (f) crimimal prosecutions under 18 U.S.C. $\S 242$ (the criminal counterpart of 42 U.S.C. $\$ 1983$ ). Id. at 502-03.

Justice White did not examine the practical availability or efficacy of these procedures. "The adequacy of these alternative remedies was evidently to be presumed from the very fact that Justice White was able to think of them." Fiss, supra note 3, at 1154. To take the most extreme example, there is no modern reported case of a state judge or prosecutor being convicted for violations of 18 U.S.C. § 242. Developments, supra note 3, at $1202 \mathrm{n} .82$.

The apphication of Younger principles im O'Shea can perhaps be dismissed in light of the primary holding that there was no "case or controversy." 414 U.S. at 504 (Blackmun, J., concurring in part). The decision nevertheless indicates a disturbing tendency to examine the adequacy of state courts most deferentially.

77. Gibson v. Berryhill, 411 U.S. 564, 577 (1973).

78. Id.

79. Gibson is the only case in which the Supreme Court has found bias sufficient to justify federal rehef from a pending state proceeding. The federal plamtiffs, optometrists employed by Lee Optical Company, were charged with "unprofessional conduct" before the Alabama Board of Optometry, on the ground that such "corporate" practice violated a recent amendment to the state optometry law. Id. at 567-68. The Supreme Court held that the Younger doctrine did not preclude federal relief in these circumstances since the Board, which was composed solely of selfemployed optometrists, had a "pecumiary interest" in the outcome of the controversy. Id. at 579. See also Kugler v. Helfant, 421 U.S. 117, 125 n.4 (1975) (extension of bias exception to state court proceedings).

80. 421 U.S. at 127-28; O'Shea, 414 U.S. at 502.

81. See, e.g., Trainor v. Hernandez, 431 U.S. 434, 447 n.10 (1977); O'Shea, 414 U.S. at 504.

82. Gerstem v. Pugh, 420 U.S. 103, 108 n.9 (1975); Lynch v. Houselıold Fim. Corp., 405 U.S. $538,555-56$ (1972). 


\section{c. Other Considerations}

The inquiry into the adequacy of the state proceedings has thus been narrowly restricted. The Court has been unwilling to consider other procedural obstacles to "full and fair" adjudication of the constitutional issue. ${ }^{83}$ Due process challenges to the state proceeding have not justified relaxation of the rule of equitable restraint, even though such charges, if proved, would certainly cast doubt on the state court's capacity to protect federal rights. ${ }^{84}$ Moreover, the Court has required equitable restraint even when presentation of the constitutional claim in the state proceeding would be "futile" in light of adverse state court precedent. ${ }^{85}$

II

\section{THe Federal INTEREST}

"Our Federalisın" is "a system in which there is sensitivity to the legitimate interests of both the State and National Governments." Equitable restraint avoids unnecessary interference with the state interest in the regular operation of its courts. The federal interest in ensuring full and fair adjudication of constitutional claims, however, nay be unduly jeopardized. Both the congressional mandate of section 1983 and a realistic appraisal of the adequacy of the state courts to adjudicate important federal claims require that the federal courts afford greater protection to this federal interest.

\section{A. Federalism, the Reconstruction Era, and Section 1983}

The Younger doctrine is based on a policy of federalisin derived frown the Judiciary Act of $1793 .{ }^{87}$ As the Court itself has recognized, however, the intervening years have seen a "vast transformation" in the concepts of federalisin, ${ }^{88}$ particularly due to the adoption of the thirteenth, fourteenth, and fifteenth amendments during the Reconstruc-

83. See Trainor, 431 U.S. at $466-72$ (Stevens, J., dissenting). Justice Stevens argued that the llinois attachment procedure features "a set of rules which effectively foreclose any challenge to its constitutionality in the Illinois courts." Id. at 467. Two lower court decisions examined more closely the procedural inadequacies of state courts. See Lessard v. Schmidt, 413 F. Supp. 1318 (E.D. Wis. 1976) (equitable restraint unnecessary because availability of appeal froin pending state civil commitment proceeding unclear); Owens v. Housing Auth., 394 F. Supp. 1267 (D. Conn. 1975) (equitable restraint not required because, inter alia, bond required of indigent claimants for appeal from state proceeding).

84. Juidice, 430 U.S. at 337 n.15.

85. Hicks v. Miranda, 422 U.S. 332, 350 n.18 (1975). The Court reasoned that state courts were capable of changing their minds and were, in any event, subject to ultimate review by the Supreme Court. Id. See also Huffinan v. Pursue, Ltd., 420 U.S. 592, 606 (1975).

86. Younger, 401 U.S. at 44.

87. Id. at $43-44$.

88. Mitchum v. Foster, 407 U.S. 225, 242 (1972). 
tion era. In conjunction with these amendments, Congress enactcd a series of statutes that expanded the power of the fcderal courts to protect the new constitutional rights. ${ }^{89}$

By the Civil Rights Act of 1871, Congress granted the federal courts jurisdiction over suits at law or in equity against "every person ... [who] subjects or causes to be subjected" another to the deprivation of any federal right. ${ }^{90}$ Congress empowered the federal courts to enforce the fourteenth amendment agaimst state action because it feared that the state courts were incapable of doing or unwilling to do so. ${ }^{91}$ The Act thus reflected the fundamental transformation in federalism since 1793; the states were no longer considered the protectors of individual rights from a tyrannical central government, but were imstead feared as posing the primary threat to such rights. ${ }^{92}$

The federal courts have regarded the Civil Rights Act, now codified in part as section 1983, as inaking them the "primary and powerful reliances" for vindicating every federal right. ${ }^{93}$ When no state proceedings are pending, federal relief may be granted although the claimant has not proved that available state remedies are inadequate. ${ }^{94}$ By contrast, when there are pending state proceedings, the Court has consistently rejected the constitutional claimant's choice of forum on the ground that the state court has the "solemn responsibility" to protect federal rights. ${ }^{95}$ This distinction is unjustified. True, the state has a legitimate interest in avoiding disruption of its courts. But if federal courts blindly defer to the state, they ignore the "intcnded scope" of section $1983^{96}$ and thereby shirk their duty to protect constitutional rights. Rather, the federal court must satisfy itself that the state court will fully and fairly adjudicate constitutional claims.

Instead of making this inquiry, current practice under the Younger doctrine defines a narrow set of "extraordinary circuinstances" that justify federal relief, and thereby excludes from equitable rehef situations where state court capacity to vindicate constitutional rights may be legitimately doubted. This displaces the federal courts' traditional deference to the claimant's choice of forum with a deference to state courts

89. This legislation imcluded the Removal Act of 1863, the Habeas Corpus Act of 1867, the Civil Rights Act of 1871 , and the Judiciary Act of 1875 (confcrring federal question jurisdiction on the federal courts). See Developments, supra note 3, at 1142, 1147-49.

90. 42 U.S.C. \$ 1983 (1976). See note 4 supra.

91. Vendo Co. v. Lektro-Vend Corp., 433 U.S. 623, 633 (1977) (Rehnquist, J.); Mitchum v. Foster, 407 U.S. 225, 242 (1972); Monroe v. Pape, 365 U.S. 167, 180 (1961). But see Wilkinson, Anticipatory Vindication of Federal Constitutional Rights, 41 ALB. L. REv. 459, 471 (1977).

92. Developments, supra note 3, at 1135.

93. See note 6 supra; note 154 and accompanying text infra.

94. See note 35 and accompanying text supra.

95. See, e.g., Younger, 401 U.S. at $45-46$.

96. Mitchum, 407 U.S. at 238. 
which vitiates the necessary inquiry. A more rigorous analysis of the adequacy of the state courts is required under section 1983.

Opponents of an active federal judiciary argue that the Civil Rights Act of 1871 was a response to a historically unique situation. ${ }^{97}$ They argue that state courts are no longer hostile to federal rights, and that the federal courts should not base the general relationship of the two court systems on a "specific enactment passed to remedy a specific problem." "98

There are at least three objections to this argunient. First, in contending that the federal courts, on an assumption of changed conditions, may simply ignore an act of Congress, the defenders of Younger expand federal court power far more than do Younger's critics. ${ }^{99}$ Second, Congress has the responsibility for repealing anachronistic legislation; yet in this case, despite ample opportunity, it has not done so. ${ }^{100}$ Finally, the argument presumes that section 1983 was directed only at outright hostility of state courts to federal claims. The Court, however, has concluded that the Act provides a federal reniedy when the state courts would fail to protect constitutional rights "by reason of prejudice, passion, neglect, intolerance, or otherwise." 101

\section{B. The Adequacy of State Remedies}

In fashioning the policy of equitable restraint, the Supreme Court has presumed the parity of state and federal courts as guardians of federal rights. ${ }^{102}$ The Court's confidence in the state courts, howcver, is shared by neither private litigants nor most commentators. Throughout this century, constitutional claimants have consistently and assiduously sought access to the federal courts. ${ }^{103}$

\section{Institutional Characteristics of State Courts}

Critics of the Younger doctrine concede that there is no concrete evidence that state judges have been less sympathetic than federal

97. Wilkinson, supra note 91 , at 471 .

98. Id.

99. See Soifer \& Macgill, supra note 7, at 1215: “'Our Federalism' has taken on many of the attributes of substantive due process. It is a creature of pure judicial will, superior to statute and to constitutional and pohtical philosophy developed over a century . . .."

100. Redish, The Anti-Injunction Statute Reconsidered, 44 U. CHI. L. REv. 717, 738 n.100 (1977).

101. Monroe v. Pape, 365 U.S. 167, 180 (1961).

102. Trainor v. Hernandez, 431 U.S. 434, 443 (1977); Kugler v. Helfant, 421 U.S. 117, 124 (1975); Huffman v. Pursue, Ltd., 420 U.S. 592, 611 (1975). Cf. Stone v. Powell, 428 U.S. 465, 493 n.35 (1976) (justifying restriction of federal habeas relief for fourth alnendment claims by the presumed parity of state and federal courts).

103. Neuborne, The Myth of Parity, 90 HaRv. L. REv. 1105, 1106 (1977). 
judges to constitutional claims. ${ }^{104}$ They have, however, sought to explain constitutional claimants' historical preference for a federal forum by isolating institutional factors that tend to inake the state courts less coinpetent or vigorous in protecting federal rights.

These critics argue that the federal bench, with life tenure and a salary significantly higher than that of most state benches, ${ }^{105}$ attracts better candidates. The federal selection process involves a more rigorous inquiry into the nominee's professional abilities than does the process in most states. Moreover, state judges will usually have less experience witl constitutional adjudication, ${ }^{106}$ fewer and less select law clerks, ${ }^{107}$ and higher caseloads ${ }^{108}$ thian their federal colleagues.

Some commentators believe the federal courts are unusually responsive to "the influence as well as the cominand of the Supreme Court," 109 while state courts inay recognize only an obligation to obey the narrow holdings of its decisions. ${ }^{110}$ More importantly, state judges face inajoritarian pressures that may affect constitutional adjudication. Federal judges are appointed for life tenure. By contrast, forty-two states require judges to face retention elections at intervals of from one to fourteen years. ${ }^{11}$

These factors inherently evade objective analysis. A broad and standardless inquiry by a federal judge into the competence or integrity of a state judge would offend the sensibilities of judges at both levels. Nevertheless, these intangible factors do indicate that state courts may often be less capable of protecting constitutional rights. This possibility requires the federal courts to be especially rigorous in testing the adequacy of state courts by factors, as proposed below, ${ }^{12}$ which are susceptible to objective analysis.

\section{Availability of Appellate Review}

The Supreme Court has justified equitable restraint toward even an erroneous state trial court decision on the ground that redress is available by appeal througli the state court network and, if necessary,

104. Id. at $1116 \mathrm{n} .46$.

105. In 1977 , a federal district judge earned $\$ 54,500$ per year. See Neuborne, supra note 103, at $1121 \mathrm{n} .61$. By contrast, the average salary of state trial judges in 1976 was $\$ 33,823$ per year. $I d$. (citing National Center for State Courts, A Survey of Judiclal Salaries in the State COURT SYSTEMS 4 (1976)).

106. McCormack, supra note 7, at 264; Soifer \& Macgill, supra note 7, at 1190.

107. Neuborne, supra note 103 , at 1122 .

108. Id. See also Stolz, Federal Review of State Court Decisions of Federal Questions: The Need for Additional Appellate Capacity, 64 CAL1F. L. REv 943, 962 (1976).

109. Id. at 959.

110. Neuborne, supra note 103 , at 1125 .

111. Id. at 1127-28.

112. See notes 181-204 and accompanying text infra. 
to the United States Supreme Court. ${ }^{113}$ The presumption that such appeals adequately protect federal rights is, however, even less well founded than the presumption of state court parity.

First, the findings of fact of the trial court are insulated from effective appellate review. Yet, these findings will often be determinative of the constitutional claim. ${ }^{14}$

Second, eventual review by the Supreine Court is by no ineans guaranteed. Although the Court inust review on appeal state court decisions upholding a state statute against a federal claim, ${ }^{115}$ almost ninety percent of these cases are disposed of without plenary consideration, ${ }^{116}$ and this percentage is increasing. ${ }^{117}$ Although summary dispositions are technically on the inerits, ${ }^{118}$ the rigor and care devoted by the Court to review of such cases may well be doubted.

Furthermore, only discretionary review by certiorari is available if the state proceeding itself is attacked on due process grounds. ${ }^{119}$ Only a small portion of petitions for certiorari are granted, and this percentage has markedly declimed over the last twenty-five years, in large part because of the Court's burgeoning workload. ${ }^{120}$

In this general narrowing of available Supreme Court review, appeals of state court decisions have especially suffered. Both as a percentage of the Court's docketed cases ${ }^{121}$ and of its full opimions, ${ }^{122}$ state

113. Huffman v. Pursue, Ltd., 420 U.S. 592, 605 (1975).

114. Neuborne, supra note 103, at 1119; Shaman \& Turkington, supra note 7, at 929; Stolz, supra note 108, at 963. The Supreme Court has itself noted the problem: "Limiting the hitigant to review here would deny him the benefit of a federal trial court's role in constructing a record and making fact findings. . . . It is the typical, not the rare, case in which constitutional claims turn upon the resolution of factual issues." England v. Louisiana State Bd. of Med. Examiners, 375 U.S. 41 1, 416 (1964). See also note 2 supra. These words are even more true today as a result of the Supreme Court's mcreasing emphasis on motivation and intent in constitutional adjudication. See, e.g., Mount Healthy Bd. of Educ. v. Doyle, 429 U.S. 274 (1977); Village of Arlington Heights v. Metropolitan Hous. Dev. Corp., 429 U.S. 252 (1977); Washington v. Davis, 426 U.S. 229 (1976).

115. 28 U.S.C. \& 1257 (1976).

116. The Court now summarily disposes of more than $87 \%$ of the appeals from state courts. Federal Judiclal Center, Report of the Study Group on the Caseload of the Supreme COURT (1972), reprinted in 57 F.R.D. 573, 605 (1972) [heremafter cited as FREUND REPORT].

117. The percentage of cases on the Court's appellate docket accepted for oral argunent has declined from 13.2\% in 1957-1958 to 7.2\% in 1971-1972. Casper \& Posner, A Study of the Supreme Court's Caseload, 3 J. Legal STud. 339, 367 (1974).

118. See Hicks v. Miranda, 422 U.S. 322, 344-45 (1975).

119. Note, supra note 33, at $615 \mathrm{n} .23$. Review of unsuccessful constitutional challenges to an official's particular exercise of his statutory powers is also only discretionary. See, e.g., Hanson v. Denckla, 357 U.S. 235, 244 (1958).

120. See Brown Transp. Corp. v. Atcon, Inc., 439 U.S. 1014, 1023-24 (1978) (White, J., disscnting from denial of writ of certiorari). The percentage of petitions for writs of certiorari granted has dropped sharply froin $17.5 \%$ in 1941 to $5.8 \%$ in 1971. FREUND REPORT, supra note 116 , at 580 .

121. Stolz, supra note 108, at 959, 978, noting that the percentage of state court cases (including in forma pauperis cases) on the Supreme Court docket dropped from more than $40 \%$ in the 
cases have dropped significantly in recent years. The theoretical availability of review by the Supreme Court thus provides no assurance that an erroneous state trial court will eventually be corrected. ${ }^{123}$

Even if meaningful appellate review is available, the Court's analysis ignores the fact that requiring such review to vindicate constitutional rights inay itself cause "irreparable injury" to both the claimant and the federal interest. ${ }^{124}$ The expense, time, and stress of an appeal can never be fully recovered by the wronged citizen. Since such costs undoubtedly deter the appeal of even meritorious claims, the federal interest in vindicating constitutional rights is also harmed.

The Court itself seems to recognize that appellate review nnay be an unreliable remedy for inadequate state courts; otherwise even exceptional circumstances would not warrant federal relief from pending state proceedings. Bad faith, flagrantly unconstitutional statutes, and even grossly biased or incompetent state trial judges would all be eventually corrected by appellate review. Yet the Court has held that the availability of such review is irrelevant when these conditions are proved. ${ }^{125}$

\section{The Need for Federal Relief}

Congress made the federal courts the "primary guardians" of constitutional rights because it beheved the state courts were inadequate to protect these rights. Moreover, the nature of the state courts, in many cases, still justifies that concern, and their deficiencies cannot be fully corrected by appellate review. The Court's current formulation of the Younger doctrime gives insufficient weight to this reality. Hence, in considering the propriety of federal relief from pending state proceedings, the Court has neglected the federal interest in the full and fair

1950 's and early 1960 's to only $26 \%$ in 1972 . Cf. Casper \& Posner, supra note 117 , at 349,351 (showing a less drastic decline, at least in part because of failure to include unpaid cases in their statistics).

122. Stolz, supra note 108 , at 951 , noting that the percentage of full court opinions including per curiam opinions (but not summary dispositions) devoted to state cases declincd froin over $30 \%$ in the mid-1960's to less than $17 \%$ in 1972 . The Supreine Court summarily disposes of inore than $87 \%$ of the appeals froin state courts. FREUND REPORT, supra note 116, at 605.

123. Relief by writ of federal habeas corpus inay also be available if the constitutional claim arises from a state criminal prosecution. Although its speed aud efficacy is subject to question, the possibility of habeas relief in criminal cases inay still be considered under the proposal advanced by this Comment. If, in a particular criminal proceeding, habeas relief provides a "plain, specdy and efficient" remedy for state court inadequacies, restraint inay be required. Such an approach will of course unake federal injunctive relief from state criminal prosecutions less likely than from other types of state proceedings.

124. See Maraist, Federal Intervention in State Criminal Proceedings: Dombrowski, Younger and Beyond, 50 TEXAS L. REv. 1324, 1334 (1972); Neuborne, supra note 103, at 1119; Stolz, supra note 108 , at 963 .

125. See, e.g., Gibson v. Berryhill, 411 U.S. 564, 577 (1972). 
adjudication of constitutional claims which is manifested in section 1983.

\section{III}

\section{The Primary Bases of Equitable Restraint}

The Younger doctrine's balance of competing federal and state interests is skewed not only by the insufficient weight accorded to the federal interest, but also by the Court's overemphasis on harins to state interests. Haruns to these interests are not of sufficient magnitude to require the present inflexible bar to federal relief.

\section{A. Equity}

The policy of equitable restraint is based on the values of "equity, comity, and federalisin."126 The traditional doctrines of equity, however, were not formulated to protect state interests froin undue federal court interference with pending state proceedings. Indeed, these doctrines inerely confuse what is essentially an issue of federalisin. ${ }^{127}$

Nornally, a plaintiff seeking equitable relief must show that he (1) lacks an adequate remedy at law and (2) is threatened with irreparable injury if relief is denied. ${ }^{128}$ In practice, the two tests merge since "irreparable injury" connotes no more than the madequacy of the plaintiff's legal remedy. ${ }^{129}$ Since these standards are viewed as a restraint on equitable power to grant relief, but not on federal power per se, federal courts have usually examined only the adequacy of the plaintiffs legal remedies at the federal level. ${ }^{130}$

The Younger doctrine lias altered this traditional analysis. In Younger, the Court held that a state criminal defendant could not show irreparable injury unless the remedy for his alleged federal wrong in the pending state proceeding was inadequate. ${ }^{131}$ In O'Shea v. Littleton, ${ }^{132}$ Justice White suggested that the availability of federal injunctive relief depended on the inadequacy of all other remedies, whether state or federal, civil or criminal, affirmative or defensive, pending or anticipated. This extension of Younger's focus on the adequacy of state remedies will significantly undermine current federal practice, since eq-

126. Steffel v. Thompson, 415 U.S. 452,462 (1975). See note 18 supra.

127. See Fiss, supra note 3, at 1107; Whitten, supra note 3, at 637 .

128. Younger, 401 U.S. at $43-44$.

129. See $1 \mathrm{~T}$. SPELling, A TREATISE ON InJunctions and Other Extraordinary RemeDIEs § 13, at 19-20 (2d ed. 1901); Whitten, supra note 3, at 601; Post-Younger Excesses, supra note 3 , at 529 n.25.

130. See DiGiovanni v. Camden Fire Ins. Ass'n, 296 U S. 64, 69 (1935); Smyth v. Ames, 169 U.S. 466, 516 (1898). But see Matthews v. Rodgers, 284 U.S. 521, 526 (1932).

131. 401 U.S. at 46.

132. 414 U.S. 488,502 (1974). 
uitable relief has been traditionally granted under section 1983 when no state proceeding is pending, without proof that all other possible reinedies are inadequate. ${ }^{133}$

This confusion over what remedies inust be examined stems from the broad language of the equitable doctrines. The real concern in the Younger context is the structure of the federal system, not the preference for legal ratlier than equitable remedies. ${ }^{134}$ The inquiry should be reformulated to reflect the dominant federalist concerns.

\section{B. Federalism}

The primary inotivation for the policy of equitable restraint is the desire to avoid undue injury to legitimate state interests. The Court has found that federal interference with pending state proceedings:

(1) prevents the state from effectuating its substantive policics;

(2) prevents the state from providing a judicial forum competent to vindicate any constitutional objections to the state's substantive policies;

(3) disparages the state courts' ability to enforce constitutional rights; and

(4) causes duplicative legal proceedimgs. ${ }^{135}$

The first liarm, arising from the state's interest in effectuating its substantive policies, implicates the values of "substantive federalisin." 136 The remaining harms involve the values of "procedural federalism," the only concern that is properly relevant to a determination of the need for equitable restraint.

\section{Substantive Federalism}

A federal court called upon to adjudicate the constitutionahity of a state statute or procedure can show deference to the state interest in enforceinent in two different ways. ${ }^{137}$ Procedural deference would require the federal court to abstain entirely from deciding the merits of the constitutional claim. Substantive deference, on the other hand, would allow the federal court to adjudicate the claim but would require that it apply a more deferential constitutional standard to the inerits of

133. Wooley v. Maynard, 430 U.S. 705, 711 (1977); Doran v. Salem Inn, lnc., 422 U.S. 922, 930-31 (1975); Steffel v. Thompson, 415 U.S. 452, 475 (1974); Monroe v. Pape, 365 U.S. 167, 183 (1961).

134. Fiss, supra note 3, at 1107. For example, the equitable doctrines suggest that restraint is not required when the pending state proceeding is equitable in nature. Yet such an exception fails to address federalist concerns, simce the state and federal interests are unchanged.

135. Huffman v. Pursue, Ltd., 420 U.S. 592, 604 (1975).

136. See note 18 supra.

137. The distinction is drawn from Redish, supra note 7 , at 478 . 
that claim. The Younger doctrine requires procedural deference, that is, dismissal of the section 1983 complaint.

Federal procedural deference results in adjudication of the constitutional issue in the pending state proceeding. Hence, the Younger doctrine should have little or no effect on substantive state pohicies. The Supreine Court's development of the Younger doctrine has always presuned that state courts will protect constitutional rights with the saine coinpetence and vigor as the federal courts. ${ }^{138}$ The logical implication of this presumption is that the state and federal courts will reach similar results in considering constitutional claims; substantive state policies cannot be affected by the forum chosen to adjudicate those claims. A substantive state pohicy, if repugnant to the federal constitution, is illegitimate and should be struck down by whichever court hears the claim. The state court inay legitimately reach a different result than would a federal court only if the state statute is susceptible to a restrictive construction to avoid unconstitutionality. ${ }^{139}$ Yet, in these cases, federal court abstention is independently required by the Pullman doctrine. ${ }^{140}$

If the Younger doctrine springs from a desire to reduce judicial interference with the state's substantive policies, ${ }^{141}$ it is ineaningful only if the state courts will uphold state pohicies when a federal court would not. The Court has never endorsed this illegitimate goal. If the state courts may reach different results than the federal courts, the Younger doctrine will yield varying standards in the several states for

138. See Trainor v. Hernandez, 431 U.S. 434, 443 (1977); Kugler v. Helfant, 421 U.S. 117, 124 (1975); Huffman v. Pursue, Ltd., 420 U.S. 592, 611 (1975). See also Stone v. Powell, 428 U.S. 465, 493 n.35 (1976).

139. See Trainor, 431 U.S. at 445; Whitten, supra note 3, at 679-80. In Pullman abstention cases, see note 2 supra, the federal court declines to construe ambiguous state laws challenged on federal constitutional grounds, leaving this task to the state courts. In diversity cases which do not involve constitutional issues, the federal courts have been far more willing to construe state law. 17 C. Wright, A. Miller, \& E. Cooper, Federal Practice and Procedure $\$ 4246$, at 500 (1978). See, e.g., McNecse v. Board of Educ., 373 U.S. 668, 673 n.5 (1963); Meredith v. City of Winter Haven, 320 U.S. 228, 235-37 (1943).

140. See note 2 supra. The state's interest in having ambiguitics of its laws resolved in its own courts has not been thought to require state court adjudication of the federal claim. A federal plaintiff whose case is postponed under the Pullman doctrine can reserve his federal claims from decision in the subsequently initiated state proceeding and present these claims again to the federal court upon conclusion of the state suit. See England v. Louisiana State Bd. of Mcd. Exaininers, 375 U.S. 411, 421-22 (1964). The continued vitality of the England rule may be in doubt given the present Court's overemphasis on affront to the state courts. See, e.g., Trainor, 431 U.S. at 443.

141. This has been the conclusion of a nunber of critics. See Juidice v. Vail, 430 U.S. 327, 346 (1977) (Brennan, J., dissenting), quoted in note 28 supra; Soifer \& Macgill, supra note 7, at 1215. Professor Fiss has discerned in the present Court "a desire to insulate the status quo from judicial interference, regardless of whether the protected institution is a judicial system, legislature, or administrative agency. I suspect that the overarching spirit of the Burger Court is a hostility toward the activism of judges." Fiss, supra note 3, at 1159-60. 
the protection of constitutional rights. Such a result is contrary to the fourteenth amendment's guarantee of a minimum national standard. The enactment of section 1983 itself, granting federal courts jurisdiction over claims of deprivation of constitutional rights, indicates Congress' intent to prevent the dilution of these rights by state court application of lax or inconsistent standards. ${ }^{142}$ Since, therefore, the state court should not reach a different result than would the federal court, equitable restramt should not affect the state's ability to earry out its substantive policies. Indeed, federal relief should be mandated when the state court would impermissibly reach a different result on the constitutional claim. Because it bars federal relief in a number of cases in which federal and state courts must reach the saine result, the Younger doctrine is unnecessary and overbroad.

The development of the "pending prosecution rule"143 also suggests that "substantive federalism" cannot be the primary basis for equitable restraint. When no state proceeding is pending, Younger does not bar federal relief froin unconstitutional state laws or procedures. Such relief, however, may obstruct substantive state policies as much as in a case where state prosecution is pending. Indeed, in such circumstances, federal relief may mvolve a greater obstruction since it could interfere with the discretion of state prosecutors not to apply state law to this situation. ${ }^{144}$ The "pendmg prosecution rule" thus suggests that the real concern underlying equitable restraimt is not the state interest in effectuation of substantive policies, but rather the state interest in the contmuity and integrity of its judicial system.

\section{Procedural Federalism}

Neither "equity" nor "substantive federalism" is a proper basis for the doctrine of equitable relief. Rather, the real purpose of the doctrine is to prevent harms to the legitimate state interest in the contmuity and integrity of its courts, harms that implicate the values of "procedural federalism."

Perhaps the most serious harm from federal imterference with pending state proceedings is delay and duplication. ${ }^{145}$ This waste of

142. Mitchum v. Foster, 407 U.S. 225, 242 (1972); Monroe v. Pape, 365 U.S. 167, 180 (1961).

143. See notes 37-41 and accompanying text supra.

144. However, the federal plaintiff must ordinarily prove a credible threat of prosecution in order to satisfy the "case or controversy" requirement for anticipatory relief. See notes 37-38 supra. If this can be shown, a state court prosecution is probably imminent, in which case the constitutional claim will eventually be adjudicated even if federal restraint is exercised.

145. Although the waste of judicial resources may well be the most serious harm prevented by equitable restraint, the Court has subordimated it to other values in developing the contours of the Younger doctrine. For example, a federal court unust dismiss a complaint on which it has begun proceedings if, before it reaches the merits, a state action is instituted, even though such dismissal wastes federal judicial resources. Hicks v. Miranda, 422 U.S. 332, 349 (1975). 
judicial resources accompanies the disruption of any type of proceeding and should normally be avoided. It must be remembered, however, that section 1983 is an "expressly authorized" exception to the AntiInjunction Act. ${ }^{146}$ The Supreme Court has never before considered the waste of judicial resources as relevant to the propriety of an "expressly authorized" mjunction of state proceedimgs. ${ }^{147}$ It has instead deferred to the congressional decision that the need for such imjunctions outweighs this waste. Moreover, if the state court proves inadequate to vindicate constitutional rights, equitable restraint will result in a greater waste of judicial resources than would federal rehef, smce the resultant appeals and retrial will consume more of the state judiciary's time and resources. ${ }^{148}$

A second harm feared by the Court is the deleterious effect of affronts to state courts arising from federal imterference with pending state court proceedings. ${ }^{149}$ Possible affronts to state courts have never been thought relevant to the propriety of mjunctions based on other "expressly authorized" exceptions to the Anti-Injunction Act, ${ }^{150}$ yet such injunctions would likewise seem to disparage state courts. When an expressly authorized exception confers concurrent jurisdiction on the state and federal courts, a federal injunction of the state proceedings implies that the state court is less competent to adjudicate the un-

146. Mitchum, 407 U.S. at 243.

147. See cases cited at note 16 supra.

148. In a broader sense, federal relief may also conserve state judicial resources by making unnecessary an unknown number of pending or future state proceedings. See Owens v. Housing Auth., 394 F. Supp. 1267, 1271 (D. Conn. 1975) (future eviction proceedings). But see Doran v. Salem Inn, Inc., 422 U.S. 922, 928 (1975), where the Court rejected a similar argument.

149. It might be argued that federal relief from pending state proceedings may be counterproductive in the long run, since such relief will somewhat impede state judges' acquisition of experience in constitutional adjudication and may inake them hostile to federal power. Thus, state courts may become less likely to vindicate constitutional rights. This argument is not only truly an affront to the state courts, but assumes that the federal courts should ignore the existence of present state court violations in order to decrease future violations of constitutional rights. The better view is that if the state court is inadequate, the federal court should intervene. The threat of federal intervention should deter future state court erosions of constitutional rights.

Federal relief, it is also argued, may create a climate conducive to state officials' abdication of controversial issues to the federal courts. Aldisert, Judicial Expansion of Federal Jurisdiction: A Federal Judge's Thoughts on Section 1983, Comity and the Federal Caseload, 1973 L. \& Soc. ORD. 557,562 . Leaving such decisions to the state courts, however, would only pronote abdication of such issues by these officials to the state courts. The Younger doctrine does not bar judicial activisin at the state level.

Finally, the local populace may be more willing to accept constitutional interpretations emanating from state rather than federal courts. Developments, supra note 3, at 1284. This argument assumes that public hostility to the restraint of the popular will inherent in constitutional adjudication stems from the "source" rather than the fact of such restraint. The reformulation of the Younger doctrine proposed here, however, acknowledges this argument by limiting federal rehef to cases in which the vindication of constitutional rights by the state courts is doubtful.

150. See cases cited at note 16 supra. 
derlying issues. ${ }^{151}$ Even when the statute confers exclusive jurisdiction on the federal courts, an injunction implies that the state court carmot recognize its lack of jurisdiction. ${ }^{152}$ The Court, nonetheless, in deference to the congressional judgment that the need for an imjunction is controlling, ignores any affront to the state courts. ${ }^{153}$

The modern development of section 1983, at least before Younger, also suggests that the affront to state courts is not relevant to the propriety of federal relief under that statute. The Court's statement that Reconstruction legislation made the federal courts the "primary" guardians ${ }^{154}$ of federal rights necessarily implies that the state courts are only "secondary" guardians of such rights. Congress, not the Court, decided that state remedies may be inadequate, and subordinated a concern for affront to state courts. ${ }^{155}$ The Court's concern for this affront calmot excuse its duty to obey the congressional inandate.

Nevertheless, affront to state courts from federal interference with state proceedings is a legitimate concern. Accordingly, the revision of the Younger doctrine proposed here seeks to avoid unnecessary affronts to the state courts. Indeed, it avoids the arbitrary affronts of the current approach since its exceptions to equitable restraint are based only on the adequacy of the state courts. When a state fails to provide a "plain, speedy and efficient remedy" for the federal wrong, any affront to its courts implicit in federal relief is deserved. The mandate of section 1983 inust then override any concern for the sensibilities of state judges. ${ }^{156}$

151. See, e.g., Porter v. Dicken, 328 U.S. 252 (1946) (Black, J.).

152. See, e.g., Kalb v. Feuerstein, 308 U.S. 433 (1940) (Black, J.); Treinies v. Sunshine Mining Co., 308 U.S. 66 (1939).

153. Nor has "affront to state courts" been considered significant in the development of doctrines which protect federal jurisdiction over federal clains. For example, the Court has created an "inphed" exception to the Anti-Injunction Act when an injunction of a state proceeding is sought by a federal agency or official. NLRB v. Nash-Finch Co., 404 U.S. 138, 145-46 (1971); Leiter Minerals, Inc. v. United States, 352 U.S. 220, 226 (1957). Since this exception is explicitly based on the fear that relegating the federal agency to the state proceeding would result in "the frustration of superior federal interests," id, the affront to the state courts is obvious.

The England proviso to the Pullman doctrine provides another example. See note 2 supra. When the federal plaintiff is directed to institute state proceedings to clarify ambiguous state law, the federal court retains jurisdiction. The plaintiff may "reserve" his federal claims from decision by the state court so that the federal court may adjudicate them when the state proceeding is concluded. The doctrine implies that state courts are not to be "trusted" with federal claims.

154. Steffel v. Thompson, 415 U.S. 452, 464 (1974); Zwickler v. Koota, 389 U.S. 241, 247 (1967). See note 6 supra.

155. Mitchun v. Foster, 407 U.S. 225, 242 (1972); Monroe v. Pape, 365 U.S. 167, 180 (1961).

156. Although not exphicitly advanced by the Court, two other "harms" resulting from federal rehief inay be thought to justify equitable restraint. Several commentators have suggested that the Court is actually motivated by a concern for the burgeoning federal docket. Fiss, supra note 3, at 1140; Post-Younger Excesses, supra note 3, at 566. Assuming the constitutionality of pruning 


\section{LiMITING THE YOUNGER DOCTRINe TO STATE Proceedings Initiated by the State}

The balance struck by the Younger doctrine rests on faulty analysis. The state has a legitimate interest in the regular operation of its courts, but its interest in its substantive policies, heavily emphasized by the Court, is actually irrelevant to the propriety of equitable restraint. Yet, on this basis, the state interest has been exaggerated and the federal interest neglected. Both the congressional mandate of section 1983 and a realistic assessment of the nature of the state courts require greater efforts to ensure the full and fair adjudication of constitutional claims.

Since the Court has left open only one inajor question-the type of state civil proceedings toward which equitable restraint is required ${ }^{157}$ critics of the doctrine have suggested that the doctrine should be limited to pending state proceedings which the state has imitiated. ${ }^{158}$ The United States Court of Appeals for the Third Circuit recently adopted this limitation in Johnson v. Kelly. ${ }^{159}$ The court reversed the district court's denial, on Younger grounds, of declaratory or injunctive relief from pending state quiet title actions initiated by private tax sale purchasers. ${ }^{160}$ The two-judge majority lield that "outside the special context of a cliallenge to civil contempt proceedings, the Younger doctrine should not be extended to cases in which the state proceedings have not been imitiated by the state itself." 161

$\S 1983$ to fit judicial workloads, equitable restraint reduces the federal docket only at the expense of state dockets which are even more overcrowded. Cox, Federalism and Individual Rights under the Burger Court, 73 Nw. U.L. Rev 1, 13 (1978); Fiss, supra note 3, at 1140. Moreover, reduction of the federal docket should properly begin with other types of cases. Diversity jurisdiction, which requires no particular expertise in federal law and which presumably "reflects negatively" on state court impartiahty towards noncitizens, is the most prominent candidate for excision. Redish, supra note 7, at 466 n.14; Developments, supra note 3, at 1129 n.86.

A more sophisticated argument in favor of equitable restraint is that it is required by the policy underlying the federal removal statutes. See Bartels, supra note 18, at 80 . This would, however, elevate an implied suggestion from 28 U.S.C. $\$ \S 1441$ and 1443 over the explicit mandate of $\S 1983$. Removal, on the one hand, and federal declaratory or imjunctive relief from pending state proceedings, on the other, are quite different "remedies" for potentially inadequate constitutional adjudication by state courts. It is by no means clear that Congress imtended equitable relief to be unavailable when removal is barred. Moreover, Professor Bartels' arguunent, taken to its logical conclusion, would bar federal relief even when the Court would allow it for "extraordinary circumstances," since none of these circumstances is a ground for removal.

157. See note 47 and accompanying text supra.

158. Johnson v. Kelly, 583 F.2d 1242, 1249 (3d Cir. 1978). See note 10 supra.

159. 583 F.2d at 1249.

160. Id. at $1244-45$.

161. Id. at 1249 . 
Utilizing the Supreme Court's approach, ${ }^{162}$ the Third Circuit evaluated the propriety of equitable restraimt by the magnitude of the state interest in the substantive policies enforced in the pending state proceeding, ${ }^{163}$ and held that only when the state brings suit to enforce these policies is the state interest sufficiently great to require equitable restramt. ${ }^{164}$ As previously noted, however, this analysis fails to recognize that substantive state policies are simply not affected by equitable restraint. ${ }^{165}$ Both the federal and the state courts would allow the effectuation of these policies if they are constitutional, and block them if they are not.

Furthernore, even if the state's substantive pohicies were relevant to equitable restraint, state initiation of the proceeding is a poor measure of the state interest in such policies. The state can effectuate highpriority policies by providing a basis for private hitigation. The state's interest in antitrust or civil rights may exceed its interest im suppressing obscenity or welfare fraud, ${ }^{166}$ yet the Third Circuit would arbitrarily "rank" substantive policies according to the prosecutorial role of state agencies.

Equitable restraint does serve the legitimate state interest in the continuity and integrity of its judicial system, ${ }^{167}$ an imterest harmed whenever a federal court disrupts any state court proceedimg. Yet the Third Circuit decision would allow federal court interference with the regular operation of the state courts even when their capacity to vindicate constitutional rights is not in doubt. The states have a right to greater protection of their interests than the Third Circuit rule affords.

Nor, for the same reason, is the federal interest in full and fair adjudication of constitutional claims served by the Third Circuit attempt to expand the power of the federal courts to vimdicate constitutional rights. ${ }^{168}$ This federal interest does not depend on the state's initiation of the pending state court proceeding. Federal relief is required only when the state courts cannot be rehed upon to vimdicate constitutional rights. Since the Third Circuit view leaves unchanged the present deferential inquiry into the adequacy of the state proceeding, the federal interest is not fully protected.

Moreover, the Third Circuit view may be foreclosed by the

162. See Trainor v. Hernandez, 431 U.S. 434, 444 (1977); Juidice v. Vail, 430 U.S. 327,335

(1977); Huffman v. Pursue, Ltd., 420 U.S. 592, 604 (1975).

163. Johnson, 583 F.2d at 1251-52.

164. Id.

165. See notes $137-42$ and accoinpanying text supra.

166. Whitten, supra note 3, at 682. But see Trainor, 431 U.S. at 444; Huffman, 420 U.S. at 604.

167. See notes $145-56$ and accoinpanying text supra.

168. Johnson, 583 F.2d at 1252. 
Supreme Court's analysis in Juidice v. Vail. ${ }^{169}$ Reversing federal relief from contempt proceedings in a suit between private litigants, the Juidice Court stressed that such interference harmed the state interest in "the regular operation of its judicial system." 170 The overwhelming inajority of lower federal courts liave required equitable restraint when rehef was requested froin state civil proceedings between private litigants. ${ }^{171}$

The Third Circuit view must therefore be rejected. It not only fails adequately to protect either the federal or state interests involved, but is of dubious validity in light of Supreme Court and lower federal court precedent. The need remams, however, for a limitation of the Younger doctrime.

Proposal

The competing state and federal interests discussed throughout this Comment can best be reconciled by a fundamental reformulation of the Younger doctrime. Equitable restraint should be required toward all pending state court proceedings that afford a "plain, speedy and efficient remedy" for the federal claim. Rather than arbitrarily limiting the Younger doctrime to certain types of state proceedings, this proposal suggests a basic revision of the inquiry into the adequacy of state courts.

The inode of inquiry for equitable restraint proposed liere was first suggested by Justice Stevens in his dissent in Trainor v. Hernandez. ${ }^{172}$ Yet the underlying rationales of the two proposals differ. Justice Stevens argued that the state interest $\mathrm{m}$ the fiscal integrity of its welfare prograin in Trainor was analogous to its imterest in tax collection. ${ }^{173}$ Hence, the state proceeding required no greater protection from federal court interference than that mandated for state tax collection by 28 U.S.C. section 1341. ${ }^{174}$ Under this standard, equitable restraint should not be required "unless the state procedure affords a plain, speedy and

169. 430 U.S. 327 (1977).

170. Id. at 335. The civil contempt proceeding involved in Juidice can perhaps be distinguished as suigeneris. See Johnson, 583 F.2d at 1252; Developments, supra note 3, at 1310-11. The state, through its judiciary, punishes the individual not for larm to the private litigant, but for disrespect to the judicial system. This distinction seems fragile, however, since the harm to the state interest in the regular operation of its courts from the disruption of contempt proceedings differs only in degree from that resulting from the disruption of any state court proceedings.

171. See cases cited at note 11 supra.

172. 431 U.S. 434, 464-70 (1977) (Stevens, J., dissenting).

173. Id. at 466.

174. Id. See also id. at 455 n.4 (Brennan, J., dissenting). 28 U.S.C. $§ 1341$ is set out at note 13 supra. 
efficient remedy for the federal wrong." 175

The rationale advanced by Justice Stevens is subject to criticism. The inquiry under section 1341 mcludes consideration of all available state remedies, whether or not available in a pending state proceeding. This standard, applied in the Younger context, would actually increase equitable restraint since the present inquiry focuses only on the pending proceeding. ${ }^{176}$ More importantly, Justice Stevens' proposal rests on the state interest in the substantive pohicies enforced in the state proceeding, an irrelevant factor for equitable restramt. ${ }^{177}$ By contrast, this proposal is predicated on a reevaluation of the state and federal interests imphicated by federal court disruption of state court proceedings. It covers all pending state proceedings and requires examination only of the capacity of state proceedings to vindicate constitutional rights.

\section{A. Standards for Propriety of Equitable Restraint}

The Younger doctrine fails to ensure the full and fair adjudication of constitutional claims required by section 1983 because the inquiry into the adequacy of state proceedings is limited in both scope and rigor. Under the current doctrine, a section 1983 claimant must prove thiat the state remedy is clearly madequate; ${ }^{178}$ if it is only doubtful, federal relief is demed. ${ }^{179}$ This Comment suggests that the federal court consider other procedural obstacles at the state level, resolving doubts in favor of the constitutional claimant.

A better balance between state and federal interests will result from the proposed approacli. While the state interest in the regular operation of its courts inay require some restriction on federal relief, it does not require equitable restraint if the state proceeding will not vindicate federal rights. When the federal defendant (usually the state itself) cannot dispel legitimate doubts raised as to the state proceeding, the federal interest in full and fair adjudication of constitutional claims outweighs this state interest.

This proposal is also justified by a realistic assessment of the state courts, one which indicates that they may tend to be less vigorous or competent in adjudicating constitutional rights. ${ }^{180}$ Although this tendency cannot norinally be proved in a particular case, it nevertheless suggests that the state remedy may not be adequate even though the procedures appear fair. Simce the intangible factors behind this ten-

175. Trainor, 431 U.S. at 469 n.15 (Stevens, J., dissenting).

176. See notes $35,37-41$ and accompanying text supra.

177. See notes $137-44$ and accoinpanying text supra.

178. See note 75 and accompanying text supra.

179. See note 82 and accompanying text supra.

180. See notes 104-12 and accompanying text supra. 
dency cannot be effectively examined, the federal courts can compensate by an especially rigorous examination of tangible procedural obstacles. A number of such procedural obstacles are discussed below.

\section{Is the State Judge Incompetent by Reason of Bias to Adjudicate the Constitutional Claim?}

Equitable restraint is not currently required if the section 1983 claimant can prove that the state judge is biased due to a pecuniary interest in the outcome of the controversy ${ }^{181}$ or bad faith towards the clainnant. ${ }^{182}$

The Court may legitimately define bias narrowly in order to avoid an inquiry on the basis of vague charges imto the integrity of a state judge. Doubts, however, should still be resolved in favor of the constitutional claimant. The Court may also legitimately consider state procedures for the disqualification of biased judges. If these procedures are plain, speedy, and efficient, equitable restraint should normally be required. The Court should not refuse, however, to examine those procedures, as it does now. ${ }^{183}$

\section{Is the Federal Plaintiff Unable to Present his Constitutional Claim in the Pending State Proceedings?}

Inability to present the federal claim in state court is recognized under the current doctrine as a ground for rejecting equitable restraint. ${ }^{184}$ However, the federal plaintiff has the burden of proving such inability. ${ }^{185}$ Under this proposal the plaintiff inust only present evidence raising doubts as to his ability to present the claim. If these doubts are not dispelled, federal relief should be allowed.

\section{Are There Legitimate Doubts That the State Court Meets "Due Process" Requirements?}

Equitable restraint should not be required if the federal court legitimately doubts that the pending state proceeding meets federal "due process" standards. ${ }^{186}$ Ratlier, the federal court should proceed to the inerits of a motion for a preliminary injunction of the state proceeding.

The Supreine Court now requires equitable restraint in the face of such "due process" attacks on the ground that such challenges can be

181. Gibson v. Berryhill, 411 U.S. 564, 577 (1973).

182. Juidice v. Vail, 430 U.S. 327, 338 (1977).

183. Kugler v. Helfant, 421 U.S. 117, 127-28 (1975); O'Shea v. Littleton, 414 U.S. 488, 502 (1974).

184. See note 81 and accompanying text supra.

185. See note 82 and accompanying text supra.

186. Trainor v. Hernandez, 431 U.S. 434, 469 n.15 (1977) (Stevens, J., dissenting). 
made in the state court. ${ }^{187}$ Even if such a claim may actually be presented in the state court-thus meeting test 2 above-the alleged due process defects may seriously hamper an effective presentation of the claim. For example, a state court challenge to a state proceeding for failure to provide an indigent with an attorney would have to be made without benefit of counsel. ${ }^{188}$

This test should not result in frivolous interruptions of state proceedings since it gives the federal courts discretion to examine only state proceedings about which legitimate doubts have been raised. In any event, no preliminary injunction of the state court will be issued unless the claimant establishes a "reasonable likelihood of success on the inerits" of the due process claim. ${ }^{189}$

\section{Does the State Proceeding Fail to Afford an Opportunity for Prompt Resolution of the Constitutional Claim?}

The Court itself has stated in dictum that the state proceeding nust allow for "timely" consideration of the constitutional issue. ${ }^{190}$ Yet, pendency alone does not imsure timely consideration. Any delay in state proceedings will prolong the deprivation of constitutional rights. Moreover, such delays increase the cost of adjudication and nay deter claimants from vindicating their constitutional rights. When the underlying claim in the state court has relatively hittle value, ${ }^{191}$ an invalid statute may avoid attack indefinitely if the state court is the only available forum. When the state proceeding does not provide for "speedy" resolution of the constitutional claim, equitable restraimt should not be required. ${ }^{192}$

187. Suidice, 430 U.S. at 337 n.15.

188. The Supreme Court has rejected this situation as an exception to the current doctrine of equitable restraint. Id.

Even if a procedural obstaele does not violate the "due process" clause, it may nevertheless cast doubt on the capacity of the state proceeding to provide a plain, speedy, and efficient remedy for violations of federal rights. See, e.g., Limdsey v. Normet, 405 U.S. 56 (1972), where the Court rejected a due process challenge to Oregon summary eviction procedures that narrowly limited the defenses tenants could present. This limitation of defenses, if constitutional claims are precluded, might nevertheless render the state proceeding "imadequate" for purposes of equitable restraint.

189. See note 46 and accompanying text supra.

190. Gibson v. Berryhill, 411 U.S. 564, 577 (1973).

191. Attachment procedures provide one example. The costs of making a constitutional challenge in state court to the procedure may, as the result of delays or other obstacles, exceed the value of the attached property.

192. Trainor, 431 U.S. at 468 n.14 (Stevens, J., dissenting). 


\section{Do State Procedures Fail to Afford an Opportunity for Prompt Appeal of an Adverse Decision on the Constitutional Claim?}

If the constitutional claimant may be unable to appeal an adverse state court judgment without undue difficulty, equitable restraint should not be required. ${ }^{193}$ The Court presently assumes that appellate review prevents "irreparable injury" from an erroneous trial court decision. ${ }^{194}$ If appellate review is not readily available, confidence in the state judicial systein is misplaced. An appeal from the state judgment may be effectively blocked by court rules or statutes which

(1) deny immediate appeal of constitutional decisions which are interlocutory; ${ }^{195}$

(2) require an appeal bond; 196

(3) allow state courts discretion to deny an appeal; ${ }^{197}$ or

(4) bar an appeal coinpletely. ${ }^{198}$

In these circumstances, equitable restraint may be inappropriate.

\section{Have the State Courts Continued to Enforce the Challenged Statute Despite a Supreme Court Decision Overruling a Substantially Identical Statute?}

This test modifies the "fllagrantly unconstitutional statute" exception hypothesized in Younger, ${ }^{199}$ but narrowly restricted if not abandoned in Trainor. ${ }^{200}$ The original exception is illogical since these are normally claims that can confidently be entrusted to the state courts. When, however, state courts continue to enforce a statute that is substantially identical to one held unconstitutional by the United States Supreme Court, ${ }^{201}$ the federal courts may legitimately doubt the competence or commitment of the state courts to protect federal rights. Equitable restraint is therefore not warranted.

193. Id. at 467.

194. Huffman v. Pursue, Ltd., 420 U.S. 605 (1975).

195. Trainor, 431 U.S. at 467 (Stevens, J., dissenting).

196. Owens v. Housing Auth., 394 F. Supp. 1267, 1270-71 (D. Conn. 1975). See note 83 supra.

197. Township of Hillsborough v. Cromwell, 326 U.S. 620, 625-26 (1946).

198. Lessard v. Schmidt, 413 F. Supp. 1318, 1320 (E.D. Wis. 1976). See note 83 supra.

199. 401 U.S. at 53-54.

200. 431 U.S. at 447.

201. This is apparently the definition Justice Brennan suggested in his dissent in Trainor, 431 U.S. at 458. He noted that the challenged Illinois Attachment Act was indistinguishable from the Georgia garnishment statute struck down in North Ga. Finishmg, Inc. v. Di-Chem, Inc., 419 U.S. 601 (1975). 


\section{Will Presentation of the Constitutional Claim in the State Proceeding Be Futile Because of Adverse State Precedent?}

Adverse state precedent does not necessarily indicate that the claimant is dooined to defeat in the state court systein, because, as the Court has pointed out, state courts can change their minds. ${ }^{202}$ Since, lowever, a state trial judge will rarely overrule established state precedent, ${ }^{203}$ an appeal will almost always be required to vindicate the constitutional right claimed. The state reinedy can hardly be characterized, therefore, as "efficient." It should be reineinbered that no federal relief will be granted under this exception if the adverse state precedent is in fact persuasive. Not even a preliminary injunction will issue unless the plaintiff establishes a reasonable likelihood of success on the inerits. ${ }^{204}$ Therefore, equitable restraint should not be required.

\section{B. The Test Applied}

This proposal requires equitable restraint only towards "adequate" state proceedings, regardless of the type of proceeding or identity of the parties. The traditional exceptions of "prosecutorial bad faith" and "flagrantly unconstitutional statutes" are eliminated. The suggested procedure is relatively simple. When the federal suit is filed, the federal defendant can move for disimssal on Younger grounds. This motion should be granted unless the federal plaintiff meets his burden of establishing doubts as to the adequacy of the pending state proceeding. If he introduces evidence of one or more procedural obstacles, so as to raise such doubts, a prima facie case against equitable restraint is established. The burden then shifts to the federal defendant to dispel these doubts. If the defendant fails to prove the state proceeding affords a plain, speedy, and efficient remedy for the federal wrong, equitable restraint is inappropriate ${ }^{205}$ and the federal court may proceed to the inerits of the substantive federal claim. ${ }^{206}$

Perhaps the chief objection to this proposal will be the increased burden placed on the already crowded federal courts. Although the hearing on the need for equitable relief might be extended and claims

202. Hicks v. Miranda, 422 U.S. 332, 350 n.18 (1975); Huffman v. Pursue, Ltd., 420 U.S. 592, 610 (1975). Both decisions, however, explicitly rejected an exception for adverse state precedent.

203. Neuborne, supra note 103 , at 1123 n.69.

204. See note 46 and accompanying text supra.

205. The resolution of doubt in favor of federal relief proposed here is similar to judicial procedure under the Tax Interference Act, 28 U.S.C. \$ 1341 (1976), quoted in note 13 supra. The Court has repeatedly affirmed that federal rehef under $\$ 1341$ should be allowed when the efficacy of the state reinedies is doubtful. Tully v. Griffin, Inc., 429 U.S. 68, 76 (1976); Township of Hillsborough v. Croinwell, 326 U.S. 620, 626 (1946); Spector Motor Serv. v. McLaughlin, 323 U.S. 101, 105-06 (1944); Mountam State Power Co. v. Pubhic Serv. Comm'n, 299 U.S. 163, 170 (1936).

206. See note 46 and accoinpanying text supra. 
for federal relief could multiply, ${ }^{207}$ full-scale constitutional adjudication in the federal courts need not increase substantially. If, as the Court now assumes, state courts are normally competent to protect federal rights, many claims for relief may be dismissed after only summary consideration.

Moreover, since the federal court examines the state proceeding generically, rejection of one section 1983 claimant should preclude similar challenges to the same type of state proceeding. For example, if a federal court once determines that the attachment procedures of a particular county or state are sufficiently adequate to require equitable restraint, future petitions for rehef from such attachment procedures can be demed summarily. If, on the other hand, a particular type of state proceeding is found imadequate, the state has an option. It may acquiesce in federal court resolution of constitutional claims arising in that type of proceeding, or it may avoid further federal interference by correcting the procedural deficiencies. In the long run, therefore, this proposal may spur state court reforms which will decrease the necessity for federal imtervention.

Finally, this proposal requires only relaxation, not complete suspension, of the inflexible bar of equitable restraint. The federal court retains substantial discretion, under traditional equitable principles, to deny federal relief from state proceedings but will, under this proposal, also have discretion to intervene if necessary for the vindication of constitutional claims.

\section{Implementation of the Proposal}

\section{By the Supreme Court}

The judicial philosophy of the present Court need not impede adoption of this proposal. This Comment has demonstrated that equitable restraint does not reduce constitutional claims nor limit judicial activism. $^{208}$ The end achieved by the policy of equitable restraint is reduction of the activity of federal judges. ${ }^{209}$ Only if this is the Court's

207. Although this proposal will lead to some short-run increase in the workload of the federal courts, this factor should not be decisive. In the first place, since equitable restraint inerely shifts the claim to another forum, federal courts lighten their dockets under the current system only at the expense of the already nore seriously overcrowded state courts. See note 156 and accompanying text supra. More importantly, the federal courts are not at hiberty to ignore an act of Congress in order to reduce their workload. If $\$ 1983$ requires federal relief from a state proceeding, the federal court cannot evade its duty.

208. See notes $137-42$ and accompanying text supra. These goals, if in fact they motivate the Court, inay be achieved more consistently and efficiently by requiring a more deferential standard in both the state and federal courts for the determination of constitutional claims.

209. Limitation of the role of the federal courts may be thought to serve the goal of reducing the federal docket. This justification is criticized at note 156 supra. Alternatively, the goal of these limitations may be a reduction of overall judicial interference with state policies by either the 
true (but unarticulated) goal would acceptance of the suggested modification be inappropriate. ${ }^{210}$

\section{By Congress}

If the Court is unwilling to accept this proposal, Congress should impose it by statute. It clearly lies within congressional power to reassert and clarify its mandate that the federal courts serve as "the primary and powerful rehances" for the protection of constitutional rights. The Younger doctrine is a judicially created rule derived from the congressional policy manifested in the Anti-Injunction Act. ${ }^{211}$ No constitutional basis for the doctrine has been suggested by the Court. The long history of statutory exceptions to the Anti-Injunction Act demonstrates that Congress has authority to require federal court imjunctions of state proceedings despite the deinands of "Our Federalism."212 Therefore, absent Court action, Congress should enact new legislation to make explicit the duty of the federal courts to grant declaratory or injunctive relief froin pending state proceedings which do not afford a "plain, speedy and efficient remedy" for the federal wrong.

\section{CONCLUSION}

The Younger doctrine is flawed by its inconsistent principles. It has been apphied only to complaints brought under seetion 1983, a statute which, the Court has held, expressly authorizes federal court injunctions of pending state proceedings. Rather than defer to the congressional decision that the need for an mjunction outweighs the harn to the state's interest, the Court has erected a policy of equitable restraint derived from values underlying the inapplicable Anti-Injunction Act.

The inconsistencies do not end here, however. The Court allows federal interference with state proceedings only in certam "extraordinary circumstances." Two of these exceptions-"prosecutorial bad faith" and "flagrantly unconstitutional statute"-allow federal relief which disrupts state court proceedings unnecessarily; these claims can

federal or state courts. This justification would be inconsistent, however, with the Court's stated presumption that the state courts will vindicate constitutional rights if the federal courts exercise restraint.

210. At least four members of the Court have indicated an acceptance of the basic principles advanced in this proposal. See Trainor v. Hernandez, 431 U.S. 434, 448 (1977) (Stewart, J., dissenting); id. at $455 \mathrm{n.4}$ (Brennan and Marshall, JJ., dissenting); id. at $469 \mathrm{n.15}$ (Stevens, J., dissenting). In addition, Justice Blackmun shows solne signs of wavering in his support of the Younger doctrine, although he appears to be searching for sone limit based on the magnitude of the state interest in the substantive policies enforced im the state proceeding. Id. at 448-50 (Blackmun, J., concurring).

211. Younger, 401 U.S. at $43-44$.

212. See note 16 and accoinpanying text supra. 
confidently be entrusted to the state courts. The federal interest in the full and fair adjudication of constitutional claims is served only by the third exception: "an inadequate state remedy." Yet the inquiry into adequacy is so deferential that the federal complaint may be dismissed even though the vindication of constitutional rights by the state court is subject to serious doubt.

Both the Court and critics of the Younger doctrine have focused on the magnitude of the state interest in the substantive policies enforced in the state proceeding, but this interest is irrelevant to the decision regarding equitable restraint. If we conclude, as does the Court, that there is a parity of state and federal courts, the state court will not afford greater protection to this state interest. Moreover, federal relief is allowed when no state proceedings are pending, yet such relief has substantially the same effect on substantive state policies as the rehef barred by Younger.

These inconsistencies may result from the Court's pursuit of an unarticulated desire to reduce judicial activism. Even if this goal is legitimate, however, the Younger doctrine is ill-adapted to achieve it. The doctrine may reduce federal claims or federal judicial activism; it does not reduce the number of constitutional claims nor lessen the responsibility of the state judiciary to invalidate unconstitutional state statutes.

More fundamentally, the Younger doctrine's balance overemphasizes state imterests. An attempt to limit the doctrine to certain types of proceedings or to certain parties does not correct this imbalance; it adequately protects neither state nor federal interests. Instead, a fundamental refornulation of the balance is required.

Congress, by enacting section 1983 , made the federal courts "the primary and powerful reliances" for the protection of constitutional rights. The federal courts may not shirk this duty. They should not delegate their responsibility to the state courts and reject the constitutional claimant's choice of forum unless they are confident that the state court will fully and fairly adjudicate the constitutional claim. The state's legitimate interest in the continuity and integrity of its judicial system does not override the federal imterest in the vindication of constitutional rights. Indeed, by expressly authorizing federal court injunctions of pending state proceedings, Congress has already made this decision for the Court.

Equitable restraint should not therefore be required unless the pending state proceeding provides a "plain, speedy and efficient remedy" for the federal wrong. If the state remedy reinams in doubt, federal rehef should be allowed. If not, equitable restramt is required.

The proposal affords consistent protection to the legitimate state 
interest in the regular operation of its courts since it is applied uniformly to all state proceedings. More importantly, it assures the full and fair adjudication of constitutional claims. If the state proceeding fails to provide a plain, speedy, and efficient reinedy for violations of federal rights, the federal courts, as the "primary and powerful reliances" of those deprived of their constitutional rights, inust intervene.

Charles R. Rice*

* B.A. 1975, University of Chicago; third-year student, Boalt Hall School of Law. This Comment is dedicated to Laurie Gould. 